\title{
The Utilization of Rifle Fire in the Field
}

\section{Major C. K. Brooke}

To cite this article: Major C. K. Brooke (1883) The Utilization of Rifle Fire in the Field, Royal United Services Institution. Journal, 27:122, 805-842, DOI: 10.1080/03071848309425437

To link to this article: http://dx.doi.org/10.1080/03071848309425437

\section{册 Published online: 11 Sep 2009.}

Submit your article to this journal $\pi$

Џll Article views: 2

Q View related articles $\sqsubset$ 


\section{OCCASIONAL PAPERS.}

This portion of the Number is reserved for Articles, either Original or Compiled, on Professional Sabjects connected with Foreign Naval and Military matters; also for Notices of Professional Books, either Foreign or English.

It is requested that communications or books for review may be addressed to Colonel Lonsdale Hale, at the Royal United Service Institation, Thitehall Yard, London, S.T.

\section{THE UTILIZATION OF RIFLE FIRE IN THE FIELD.}

By Major C. K. Brooke, Ist Batt. East Yorkshire Regt.

Usrortusatel the study of the science of "Fire Tactics" has been so neglected in this couniry, and so little data has been collected, that it is necessary to appeal chiefly to the results of experiments carried out abroad for the facts on which to base a theory of how best to utilize the power of the rifle in the field.

This paper will therefore be based upon, and make free use of, the tables, deductions, and criticisms contained in a "Commentary on the German IIusketry Instructions" which appeared in 1882 in the "Rerue Mrilitaire de letranger."

The result of the experimental firing conducted near Dungeness in 18 $79-80$ will also be made use of as far as practicable.

Firing in the field may be divided into two categories : Individual, and Collective; the former being the fire of individual men when left to their own initiative, the latter the fire of several men acting together under the orders of a superior.

The discussion of the subject divides itself naturally into two parts; and it is proposed in the first to deal with individual fire, and in the second with collective tire.

\section{PART I.}

\section{Individual Fir.e.}

The questions which mainly concern the individual firing of men are :-

"a." "The relation which exists at each distance between the size of the object aimed at, and the dimensions of the grouping of a series of shots at the same distance.

"b." The point to aim at.

"c." The employment of fixed sights.

"d." The linit of effective individual fire.

"a." The Relation betteen the Objective and Shot Gronps.

The influences which act on rifle firing are so diverse that even when the same man with the same rifle fires a series of about 50 shots without committing the least error, and aiming steadily at the same spot, the bullets 
striking a vertical target cover a surface more or less large; this surface represents the vertical grouping of the shots of the series at this distance, and may be called a vertical shot group.

The combined trajectories of all these shols constitute their "gerbe," and this may be likened to a curved horizontal cone, having its apex at the muzzle of the rifle, and its base at the object aimed at.

Plate XXV, Fig. 1, extracted from the "German ifusketry Regulations," represents this gerbe or sheaf of shots; and $a_{5} \mathrm{O}_{4} b_{4}$ its terminal vertical shot group.

The horizontal grouping of the shots of a series is obtained from the vertical shot group by calculating the distance each shot would travel before reaching the ground. Since the drop of a bullet which strikes the top of a six foot high target is known for every distance, the calculation of the drop of all other shots can be practically determined by simple proportion. For example, the drop of a bullet at 500 yards when fired from the Henry-Martini rifle is, from the Dungeness experiments, 64 feet in 6 feet ; consequently, if a shot struck the target 4 feet from the ground, its horizontal projection behind the target would be $\frac{a}{4}=\frac{64}{2}$, or the bullet would reach the ground $42 \frac{1}{2}$ feet in rear of the target. Plate XXV, Fig. 2(Ger. Mus. Regn.) graphically represents the horizontal grouping of a series of shots. It has been found by experinent that in these groups, the shots tend to form a sort of nucleus in the centre, and to be more scattered at the margin.

The vertical grouping of the shots from the Mauser rifle takes the form of a circle as far as $150 \mathrm{~m}$. inclusive, and thence the shot groups assume an oval shape of which the longer axis is rertical. The axes of these ovals go on increasing as the distance becomes greater, and their dimensions also vary more or less in accordance with the accuracy of the shooting of each rifle.

The dimensions of the rertical shot groups of the Mauser rifle are shomn in Table 1 ; in which will be seen the percentage of abnormal hits which are subtracted at each distance in Germany. The centre of the shot group is determined by the position of a point which has an equal number of shots above and below it; and an equal number to the right and left of it. Plate XXV, Fig. 3 (G. M. I.) illustrates this. In France, it is not thought that this central point is determined by such a rudinentary method.

Before proceeding further it will be necessary to assume some dimensions for the objects which are most frequently fired at in the field : the following will be the data made use of in this paper; and are, except the height of a standing man, the dimensions adopted in Germany :-

\begin{tabular}{|c|c|}
\hline Min standing & \\
\hline Mán standing & or 5 \\
\hline • & \\
\hline 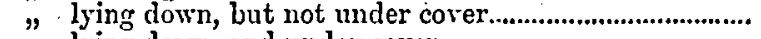 & 0.4 \\
\hline . & 0.35 \\
\hline 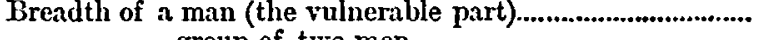 & $0: 40$ \\
\hline 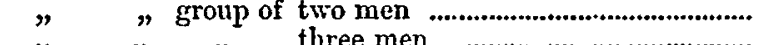 & $080 \%$ \\
\hline A"civalry" sol & $\begin{array}{l}1.20 \\
2 \cdot 00\end{array}$ \\
\hline
\end{tabular}

The relation between the above dimensions and the areas shown in Table 1 must always be borne in mind; for allowing that the sighting of a series of shots is correct, and that no mistake is made in aiming, still these shots will only strike the mark so long as their grouping and the objective have the same extent of surface. When a distance is reached at which a shot group has a larger surface than that of the objective, then many of the bullets, though well directed, will mis 3 their mark; the number of misses incrensing in proportion as the area of the shot group exceeds that of the objective. 
For example, with correct sighting and accurate firing, it is neccssary that the objective at $300 \mathrm{~m}$. should be $48 \mathrm{cms}$. wide, and $58 \mathrm{cms}$. high, in order that 95 per cent. of the shots should strike it; if the object fired at had a less width or height, then a proportionably smaller number of hits would be made.

Passing on, the several trajectories which together define the shape of the "gerbe" must he glanced at. The mean trajectory of a rifle for any distance can be graphically traced by connecting the centres of a series of intermediate vertical shot groups, and is represented in Plate XXV, Fig. 1, by the line $a, 0 \ldots o_{5}$. The upper trajectory is traced by joining together the upper parts of these same shot groups ; and the lower trajectory by joining all the lower parts of the groups: the line $a, a_{1}, \ldots a_{6}$ shows the former, and the line $a, b, \ldots b_{4}$ the latter.

The ordinates of the mean trajectory are the distances of the centre of the shot groups above the line of sight ; the ordinates of the upper and the lower trajectories are obtained by adding to, or subtracting from the ordinates of the mean trajectory, half the vertical axes of the shot groups at the several distances.

For example, to find the ordinate of the upper trajectory of the $400 \mathrm{~m}$. gerbe, at say $300 \mathrm{~m}$. ; arld $29 \mathrm{cms}$., half the rertical axis of the shot group at $300 \mathrm{mll}$, to $1 \cdot 14 \mathrm{~m}$., the ordinate of the $400 \mathrm{~m}$. trajectory at the same distance, and their sum 1.73 m. is the ordinate required. Table 2 (G1, Ger. MIus. Inst.) shows the ordinates of the trajectories with the fixed sight of $270 \mathrm{~m}$., the flap sight of $350 \mathrm{~m}$., and the sight of $400 \mathrm{~m}$.

If a gerbe be pictured mentally as a solid curved cone, lengthened by the elevation given to it, and having its terminal vertical area rapidly increased as it is directed on more and more distant objects ; then the menning of the term "shot groups" at rarious distances will become apparent, and they will be seen to be merely a series of vertical sections taken through the imaginary solid cone at the different distances. Irooking thus at a gerbe, the conclusion arrived at from the foregoing investigation may be defined under the statement, that, in individual firing, the relation between an objective and a shot group is the relation that exists between their respective areas at the distance fired at.

\section{"b." The Point to ain at.}

The shot groups in individual firing have hitherto only been considered with reference to the object aimed at, when this has been at the same distance as that of the sight made use of : they must now, however, be considered with reference to an object which is at a less distance than that of the sight employed : there are two cases to examine.

(1.) When the aim is directed at the object.

(2.) When the aim is directed at an olject whose distance from the firer corresponds with the sight made use of.

(1.) For example, in the first case let the aim be directed with the $350 \mathrm{~m}$. sight, at the foot of an object $300 \mathrm{~m}$. from the firer; then if reference be made to Table 2 it will be seen that the centre of the shot group at this distance is $70 \mathrm{cms}$. (the ordinate of the $350 \mathrm{~m}$. trajectory at $300 \mathrm{~m}$.) above the line of sight, and as this is directed at the foot of the target, the centre of the shot group may be taken as $70 \mathrm{cms}$. above the ground.

But if under the same conditions the aim had been directed at the centre of the target $(90 \mathrm{cms}$. above the ground) then the centre of the shot group would be $90+70 \mathrm{cms}$. or $1 \mathrm{~m} .60 \mathrm{cms}$. above the ground : and as the semi-diameter of the vertical axis of the shot group at $30 \mathrm{C} \mathrm{m}$., Table 1 , is $29 \mathrm{cms}$., then the upper trajectory of the gerbe would pass $1 \mathrm{~m} .60 \mathrm{cms}$. $+29 \mathrm{cms}$, or $9 \mathrm{cms}$. above the top of the target, and in consequence many shots would fail to hit: 
whereas, if the aim had been directed at the foot of the target the whole of the shot group would lave struck it.

The movement of the shot group is well shown in Table 3, in which the upper and lower trajectories of $350 \mathrm{~m}$. gerbe are recorded as the aim is directed either at the foot or the centre of the targets placed at intervals of $50 \mathrm{~m}$. from the firer. The trajectories are obtained as said before by adding to or subtracting from the orlinates of the mean trajectory the semidiameters of the vertical axes contained in Table 1.

(2.) In the second case the position of the firer has to be taken into account, ns the aim is directed at a mark beyond the object fired at. The heights of the different firing positions are in Germany laid down as under :-

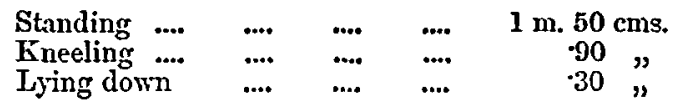

It is evident, since the trajectory follows the line of sight, that if the latter be raised the ordinates of the former will be increased at all distances between the firing point and the object aimed at. Take for example the line of sight proceeding from a man standing to the centre of a target $1.80 \mathrm{~m}$. high, and the liue of sight direeted by a man kneeling to the same place on the target: the former is a line falling from $1.50 \mathrm{~m}$. to $90 \mathrm{cms}$, the latter is a horizontal line $90 \mathrm{cms}$. above the ground; the fring position of a man kneeling and the centre of the target coinciding in heiglt. Table 4 shows the height of the ordinates of these sereral lines of sight at different distances, under the conditions that the aim is either directed at the foot of the target, or at its centre.

To obtain the ordinates of the mean trajectory of $350 \mathrm{~m}$. gerbe, it is only necessary to add to the ordinates of the line of sight in Table 4 , the ordinates of the $350 \mathrm{~m}$. trajectory as giren in Table 2 ; the result is shown in Table 5. In order to further define the movements of the shot groups at intermediate distances, Tables 6 and 7 have been added; they have been obtained respectively by adding to or subtracting from Table 4, the semi-diameters of the vertical axes contained in Table 1 .

Using the above data, the position of the shot group on a target at $300 \mathrm{~m}$. can be examined, when aim is taken with the $350 \mathrm{~m}$. sight at another target at $350 \mathrm{~m}$.

Let aim be first taken at the foot of the $350 \mathrm{~m}$. target by a standing man; then by Table 6 , the upper trajectory of the shot group at $300 \mathrm{~m}$. will be only $1.20 \mathrm{~m}$. from the ground; whereas, if the firer aimed at the centre of the target it would be $1.97 \mathrm{~m}$. to $17 \mathrm{cms}$. off the target : again, if the firer kneels, and aims at the bottom of the target, the upper edge of the shot group will be $1.11 \mathrm{~m}$. above the ground; but if he aims at the centre of the target it will then be $1.89 \mathrm{~m}$. from the ground, that is $9 \mathrm{cms}$. off the target.

Thus when firing either standing or kneeling, and aiming at the centre of the distant target, the upper part of the $350 \mathrm{~m}$. gerbe passes abore the $1.80 \mathrm{~m}$. internediate target, placed at $300 \mathrm{~m}$. And the deduction may be made that when an object is $50 \mathrm{~m}$. short of the mark aimed at, aim should be taken at the foot of this mark, both when firing standing or kneeling.

Before proceeding to consider generally how the $350 \mathrm{~m}$. gerbe acts at all distances intermediate between the firer and $350 \mathrm{~m}$., a glance at a battle-field must be taken. In a battle which is intended to be brouglit to an issue, one side must act on the offensive, the other on the defensive; the rotes may be interchanged, but at any given moment the opposing front lines of the adversaries must be either advancing to the attack, or staying still to defend the position attacked; therefore the distance between the two sides tends to diminish, and it becomes most important that the intervening space between the adversaries should be swept by a storm of bullets. The ideal of rifle fire 
on the field is reached, when no bullet in the intervening space between the opponents passes over the head of a standing man: that is, does not rise higher than 1.60 m., or 5 feet 4 inches above the ground.

Other kinds of actions there are: demonstrative, and retreating; in the former a delaying fire is made use of, and time is given to work out distances; in the latter, the victors being safe, have to raise their sights as the enemy flies before them. But before the action is decided, when the strain is most intense and tine most limited, then fingers must hold firmly the rifle which may at any moment be required for use in the way our forefathers handled it; they cannot be loosened to fiddle with a sight, or to adjust it to distances of 50 yards, nor can the eyes be lowered for the purpose, or taken off the enemy, when he is advancing on us, or we on him.

In discussing this question of rifle fire in the intervening space between closely opposing forces, tables based on the employment of the $350 \mathrm{~m}$. sight will alone be made use of ; for if they serve to prove that it is advantageous under the above circumstances to aim at a certain portion of the objective, then analogous tables based on the use of other sights are not needed as they would only tend to confirm the same fact.

If Table 5 be examined it will be seen, that when firing standing and aiming at the bottom of the target, the centre of the shot group will pass over the heads' of standing men for $150 \mathrm{~m}$, riz., from $50 \mathrm{~m}$. to $200 \mathrm{~m}$.: if aim is taken at the centre of the target, the centre of the shot group will clear a man for $250 \mathrm{~m}$., viz, from $50 \mathrm{~m}$. to $300 \mathrm{~m}$. Again, Table 7 shows that when the firer is standing, and aim is taken at the bottom of the target, the lowest part of the gerbe passes orer a standing man from $50 \mathrm{~m}$. to $200 \mathrm{~m}$., and if aim is taken at the centre of the target from $50 \mathrm{~m}$. to $250 \mathrm{~m}$. Table 6 shows that the upper part of the gerbe under similax conditions passes respectirely over a man's head from $50 \mathrm{~m}$. to $250 \mathrm{~m}$., and from $50 \mathrm{~m}$. to $300 \mathrm{~m}$. Further, if a man is firing lying down and ain is taken at the middle of the target, the whole of the slot groups for $100 \mathrm{~m}$., viz., from ' $150 \mathrm{~m}$. to $250 \mathrm{~m}$., pass over a man's heid; whereas if aim is taken at the bottom of the target, the whole of all the shot groups strike a standing man.

From all these facts the deduction may be: that when aim is taken at the bottom of an object the intervening space swept by the gerbe is lengthened.

Another point in the question must be considered, viz., the effect of taking a fine or full sight. At $300 \mathrm{~m}$., if the former is made use of, the mean trajectory is depressed $15 \mathrm{cms}$., and if the latter, it is raised a similar amount. Looking at Table 5, it will be seen that at $300 \mathrm{~m}$. the use of the full sight will raise the centre of the $350 \mathrm{~m}$. gerbe above the liead of a standing man, when aim from the kneeling or. lying down position has been directed at the centre of the target; whereas under similar conditions, if aim had been taken at the foot of the target the full sight would not have caused any shots to pass over a man's head. Hence the derluction may be made, that aiming at the foot of an object diminishes the eril resulting from the use of a full sight.

When a fine sight is employed in conjunction with aiming at the bottom of the target more ricochets are caused, and this brings into prominence an objection that might be raised to aim being always directed at the foot of an object, namely, that when the correct sighting is used only one-half of the shot group will directly strike the mark. The action of ricochets can bo studied by the light thrown on them by the Dungeness experimental firing; in the report it is stated that "the bulk of ricochet hits is effective," and that the mean rise of a bullet is twice that of its drop. Having this data, the objection raised can be met, and the following example may serve as an illustration. Let aim be taken with the $350 \mathrm{~m}$. sight at the foot of a target at $350 \mathrm{~m}$., then by Table 7 the lower trajectory. will theoretically pass $34 \mathrm{cms}$. 
below the target, but the bullets will really strike the ground in front of the target. This distance may be obtained proportionally from Tuble $\mathrm{T}$, which shows that a bullet fired under the circumstances above stated falls 39 cms. in the last $25 \mathrm{~m}$., consequently the bullets in question will strike the ground $18 \mathrm{~m}$. from the target; since the rise is twice the drop, the bullets in ricocheting will strike the target $2 \times 34 \mathrm{cms}$., or $68 \mathrm{cms}$. from the ground. It inay be noticed that the height at which the shots of the lower trajectory ricochet into the target, always coincides with the vertical axis of the shot group at the distance fired at.

As the lower trajectory represents the path of the bottom bullet of a gerbe, it follows that in the c:ise discussed all the bullets strike the target.

From Table 1 it will be seen that up to $600 \mathrm{~m}$. the longer axis of a shot group does not exceed a man's height; consequently the deduction may be made that if aim is taken at the foot of a standing man he is liable to be struck by all the ricochets proceeding from the lower trajectories of the sereral gerbes up to $600 \mathrm{~m}$.

Tactical reasons have been adduced in support of the principle of aiming at the foot of the object, and they have been stated as follows:" If the smoke hides the objective it is impossible to aim at its centre, while on the contrary it is very easy to distinguish and aim at a mark taken on the line of separation which exists between the cloud of smoke and the ground, this line being clearly defined in the field. On the other hand, if the adversary, while advancing, disappears behind some artificial shelter, or is lost to sight in a depression in the ground, aim can still be taken at the entrenchment, or at the mark on the ground previously selected, the bullets thus fired will have a good cliance of being well directed. Besides, is not the soldier in the heat of action always tempted to take too full a sight ? in naking lim aim at the bottom of the object a compensating influence is brousht to bear on this fault, which is so common amongst men in the field." Further by thus aiming at the bottom of the objective the gerbe is lowered, and the enemy as he advances, plunges himself more deeply into the rain of bullets, instead of getting out of it, as he would, if aim had been taken in the centre of the object fired at.

To sum up, aim in individual firing should always be directed at the foot of the object for the following reasons :-

"a." That the intervening space swept by the gerbe is lengthened.

" b." That the evil arising from the use of a full sight is mitigated.

"c." That the ricochets of the lower half of all gerbes up to $600 \mathrm{~m}$, are better utilized.

"d." That tactically it is adrantageous.

\section{"c." The Employment of Fixed Sights.}

It has been shown that for tactical reasons soldiers cannot adjust their sights at the critical moment of the combat, either when they are adrancing rapidly on the enemy or he on them. The maximum distance which separates the opposing sides at the commencement of this stage of an action, may be assumed to be about 400 yards $(360 \mathrm{~m}$.), therefore a fixed sight or fixed sights are required to sweep this space. The number of sights employed must be limited, one would be best, but two are the most that would fulfil the required conditions. In Germany two are made use of, viz., a $270 \mathrm{~m}$. fixed sight, and a $350 \mathrm{~m}$. easily raised flap sight. An examination of the action of these tro sights will be sufficient to prove if the principle of the use of fixed sights is advantageous or not. Unfortunately the question cannot be discussed with reference to our own Martinj-Henry rifle, as no accurate data is published, and it is very doubtful if the necessary long-continued experimental tiring has ever been carried out.

To aid in the investigation, Tables 8-11 have been calculated in a similar 
manner to Tables 4-7; and, in addition, the action of ricochets has been alded to Tables 5-7, and embodied in Tables 9-11.

First with regard to the action of the 270 m. sirht: if Tables 9-11 be examined it will be seen that the whole of the gerbe proceeding from men firing in the standing position, and aiming at the bottom of a target, will strike a standing man ( $5^{\prime} 4^{\prime \prime}$ or $1^{\circ} 60 \mathrm{~m}$.) throughout its course up to $270 \mathrm{~m}$.; with the solitary exception that the bullets in its upper trajectory pass 2 inches above a man's breast at $190 \mathrm{~m}$. If the action of ricochets is included, the same tables show that the ground swept by the gerbe may be extended to $300 \mathrm{~m}$. ; thus, practically, men firing standing and aiming at the foot of their objective, cover with their fire any standing man up to $300 \mathrm{~m}$. Again, if the ordinates of the gerbe of men firing in the knceling or lying down position be looked at, it will be seen how much closer the gerbe sweeps to the earth; and as few men in action would be firing otherwise when the enemy was within $300 \mathrm{~m}$. of them, the eficiency of the gerbe is largely increased.

Another point must be taken into account, that is, when aim is taken at any object at a less distunce than $270 \mathrm{~m}$., the line of sight is proportionably depressed, and the gerbe in consequence passes closer to the ground.

From all the abore it may safely be concluded that the use of the fixed $270 \mathrm{~m}$. sight, combined with aiming low, enables all the ground in front of the firer to be swept up to $300 \mathrm{~m}$.

To cover the remaining space, viz., up to $360 \mathrm{~m}$. or 400 yards, the $350 \mathrm{~m}$. sight will suffice; looking at 'Tables 5 to 7 it will seen that with a standing man aiming at the foot of a target the upper trajectory of the $350 \mathrm{~m}$. gerbe at $300 \mathrm{~m}$ is only $1.20 \mathrm{~m}$, above the ground ; and that at $360 \mathrm{~m}$., including the action of ricochets, no shols rise higher than $1.06 \mathrm{~m}$.; again, the mean trajectory at $300 \mathrm{~m}$. will strike a kmeeling man, and at $360 \mathrm{~m}$. its ricochets only rise $0.06 \mathrm{~cm}$. above a man lying down; hence with flap sight of $350 \mathrm{~m}$. all the ground between $300 \mathrm{~m}$, the limit of the action of the $270 \mathrm{~m}$. sight, and 400 yards, is thoroughly swept; and the conclusion is arrived at that two sights, combined with aiming at the foot of the mark, are suflicient to keep all the ground up to 400 yards well under fire.

Incidentally it may be observed that the analysis of the action of these two sights affords a strong argument in favour of reducing the trajectory of the rifle, for if this were flattened one fixed sight would cover all the ground up to 400 yards.

\section{"d." The Limit of Effective Individual Fire.}

Individual fire has previously been defined as " the fire of individual men when left to their own initiative;" that is to say, it is the fire of skirmishers freed from all directions, therefore free to choose their object, their sight, and to regulate their own consumption of ammunition. Accepting this definition, it becomes necessary to fix some limits within which this fire may be employed, otherwise a serious waste of ammunition would take place. These limits may be theoretical or practical ; the first case postulates a very frood shot making no mistakes, and knowing the exact distance; the second assumes that two factors, at least, will always militate in the field against. attaining the theoretical result, viz., errors in aiming, and errors in estimating distance.

-First, with regard to the theoretical limit: if infantry fire against infantry the largest objective is a standing man, $1.60 \mathrm{~m}$. or 5 feet 4 inches high ; turning to Table 1 , it will be seen that the hejght of the shot group at $600 \mathrm{~m}$. is $1.58 \mathrm{~m}$., and its width $1.26 \mathrm{~m}$; this may be taken to represent a group of three men standing side by side; hence a perfect shot, knowing the exact distance, may lare a chance of putting 91 per cent. of his shots into these 
three men. But if this same man, under similar conditions, were to fire at a standing man at $700 \mathrm{~m}$. nearly a fourth of his shots must pass over the man's liend; for the height of the shot group at $700 \mathrm{~m}$. is $2 \cdot 12 \mathrm{~m}$., whereas the height of a standing man is only $1.60 \mathrm{~m}$. Consequently with regard to firing at infantry the theoretical limit of individual fire may be fixed at $600 \mathrm{~m}$.; provided, that the aim is absolutely correctly taken, that the exact distance is known, and that the objective is not less in size than three men standing side by side. The mere statement of this conclusion is enough to show its eminent unpracticability, and that to let the mass of men fire individually at this distance would lead to an enormous loss of ammunition.

What then is the practical limit for the employment of indiridual fire in the field? As said before, two factors govern it: errors, in aiming, and in judging distance. Errors in aiming cause either an increase or decrease of angular elevation, and a consequent rise or fall of a bullet on a vertical target, and it has been stated that these errors range from 3 to 6 and up to 12 millimetres in the first metre measured from the muzzle of the rifle: this is equal to angular errors of about 10,20,30 minutes, and gives rise to a rertical displacement of :-

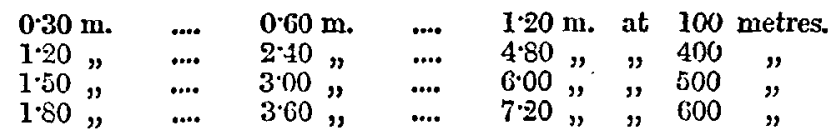

But though the vertical displacement increases with the distance, the lorizontal decreases ; for example, at $200 \mathrm{~m}$. an error of 1 minnte gives rise to a horizontal displaccment of about $8 \mathrm{~m}$, whereas at $500 \mathrm{~m}$. this is reduced $5 \mathrm{~m}$., and at $1,000 \mathrm{~m}$. to $3 \mathrm{~m}$.

Assuming that under the circumstances of firing at an enemy, the majority of men fire high with the minimum error of 10 minutes, their shots at $400 \mathrm{~m}$. will be raised $1.2 \mathrm{~m}$. above the ground; if to this be added half the height of the shot group at this distance, $0.12 \mathrm{~m}$., the centre of the gerbe will be $1.62 \mathrm{~m}$. high; that is, the mean trajectory will just clear the heads of standing men. Again at $600 \mathrm{~m}$. the mean trajectory will be $209 \mathrm{~m}$. above the ground, $0.49 \mathrm{~m}$. above the head of a standing man. Hence on account of inaccuracies in aiming, and the tendency men have to fire high in action, the limit of individual fire from this point of view should be fixed at $400 \mathrm{~m}$.

With regard to errors in estimating distance, taking into account the diffculty of judging distance in action, it is fair to assume that errors of a tenth of the distance up to $300 \mathrm{~m}$., a serenth up to $600 \mathrm{~m}$, and a sixth up to $1,200 \mathrm{~m}$., will be committed. In Table 12, the probable errors in judging distance from $400 \mathrm{~m}$. to $600 \mathrm{~m}$. are compared with the extent of ground swept by the entire gerbe at each distance, assuming that the objective is a standing man, $1.60 \mathrm{~m}$. high. From this table' it will be seen that at $400 \mathrm{~m}$., errors in judging distance can cause but fer shots to miss, as the zone swept by the entire gerbe is $106 \mathrm{~m}$. in extent, while the probable miscalculation of distance is only $57 \mathrm{~m}$. At $450 \mathrm{~m}$. these spaces are practically equal, and most of the shots will hit the objective; but at $500 \mathrm{~m}$. an error of $21 \mathrm{~m}$. will prevent any shots striking the object; hence from this standpoint the limit of individual fire must be fixed at $450 \mathrm{~m}$.

Taking both the above factors into consideration, the limit of effective individual fire at standing men may be placed at $400 \mathrm{~m}$. or 450 yards for the great majority of men, but a good shot, hnowing the exact distance, may be permitted to fire up to $600 \mathrm{~m}$. or 650 yards. The limit of individual fire at kneeling men may from similar calculationz be placed at $400 \mathrm{~m}$. or 450 yards for good shots, and at $250 \mathrm{~m}$. or 275 yards for ordinary men; lastly, the limit for individual fire at men lying down may be fixed at 200 yards. 


\section{PART II.}

\section{Collective Fire.}

Before proceeding to an examination of the action of collective fire, it is well again to point out, that the limits for individual fire laid down in the first part of this paper apply solely to the Mauser rifle: a rifle with a lower trajectory would have a flattened gerbe, with diminished transverse section, and hence the limit for its employment in indiridual firing would extend beyond that fixed for the Mauser; still, at the same time, the principles on which these limits are fixed remain the same in both cases. Similarly, in the following discussion, the action of the Mauser rifle will alone be under review, but the principles which underlie its usefulness in collective firing will apply to any other rifle; hence the study becomes useful as a clue to the study of the action of all rifles.

Collective fire, as said before, is "the fire of several men acting together under the orders of a superior," and since at $400 \mathrm{~m}$., the limit of individual fire from the 3Lauser rifle is reached, the action of collective fire must be studied from $450 \mathrm{~m}$. onwards.

\section{Irethod of Obtaining a Record of the Result of Collective Fire.}

The plan adopted in Germany to obtain a record of the flight of bullets is approximately the same as that in France, Italy, Austria, and England; but, since fuller details of the method of conducting these researches are published in the first-named country, the German plan will be described as a type of how such investigations are generally carried out.

The effects of collective fire have been determined in Germany by means of experiments on a large scale carried out at the Hrusketry School at Spandau. The experiments extended over a considerable length of time, and were executed by firing a great number of rounds in order to reduce to a minimum all abnormal influences. The men firing were relieved from time to time, and were sent to Spandau from their regiments only a few days before taking part in the experiments ; they were second and third class shots, that is, men respectively in their second or first year's service; they were in marching order, and had to make it march of some hours before arriving on the practice ground. The fire was conducted by means of rolleys fired by men lying down using rests, and at targets $1.80 \mathrm{~m}$. (6 feet) high and $20 \mathrm{~m}$. (22 yards) wide. The number of men firing varied from 10 to 50 , as a rule 25 were employed; the number, experiments have shown, has hardly any influence on the results, provided there are at least 10 men firing. The men vere extended orer $20 \mathrm{~m}$., a space equal to the extent of the target, and were ordered to aim straight to their front and at the bottom of the first target of the series.

Care was taken to choose a. flat surface parallel' to the line of sight, on which to place the targets, thus the tops of all the targets of the series were practically level. The targets were made of some slight material corered with paper, and stretched on easily movable frames. 'They were arranged in column, and were separated by distances deduced from the total theoretical length of the dangerous zone, in such a manner that a bullet which grazed the top of one target struck the bottom of the target next behind it; under these conditions, each bullet theoretically left but one mark on the entire series of targets. The intervals between the targets are shown in Table 13, which is a copy of Appendix $L$ of the German Musketry Instructions of 15th November, 187\%. In order that all the shots should be registered, the targets had a depth of 150 to $200 \mathrm{~m}$. when a single sight was used, and a depth of 300 to $400 \mathrm{~m}$. When two sights, with a difference of $100 \mathrm{~mm}$. between them were employed. For example, with the line of sight of $600 \mathrm{~m}$., the 
targets were placed at $535,586,620,669$, and $700 \mathrm{~m}$, thus having a depth of $165 \mathrm{~m}$.

When the firing was concluded the number of hits were counted to verify that each bullet had left but one mark of its passage; then the position of the hits on each target were taken off, and from this vertical record the horizontal representation of the grize of each bullet was calculated.

\section{General Results of Collective Fire.}

Such is the method by which the data for the examination of the action of collective fire was obtained in Germany. The results, broadly speaking, are that the hits spread remarkably evenly over a space lengthened in the direction of the line of fire and depending for breadth on the extension of front given to the fire. A nucleus shown by a slightly denser grouping of the hits, appears towards the centre of the surface struck; the hits outwards to the periphery becoming more and more seattered. The regularity with which the lits are distributed is due to the reciprocal action of the different influences which tend to make the bullets spread, and it is to this reciprocal action that the great value and great certainty of collective fire is due. The longitudinal dispersion remains nearly constant at all distances, and up to $1,400 \mathrm{~m}$. it has even a tendency to diminish; this is due as said before to the fact, that the same angular error in elevation has a diminished influence on the range of the bullet in proportion as the distance is increased.

\section{Construction of T'ables to show the Result of Collective Fire.}

In order to arrive at the value of the experimental firing, the results obtained on a series of targets placed as before described are decomposed, under the supposition that targets $1.80 \mathrm{~m}$. bigh, and equal in width to the gerbe, are placed at intervals of $10 \mathrm{~m}$. along the entire path of the bullets; then the number of hits which would have struck each of the targets is calculated, and thus the terms of the series required are obtained. For example, in order to find the number of hits in a target at $400 \mathrm{~m}$., it is only necessary to count the number of grazes that lie between its position and that of a parallel target $75 \mathrm{~m}$. in its rear, since the bullets making the grazes must hare passed within 6 feet of the ground at $400 \mathrm{~m}$. ; the clangerous zone or " margin" of the $400 \mathrm{~m}$. trajectory with reference to a 6 feet target laving a depth of $7 \cdot 5 \mathrm{~m}$.

The target which receives the largest number of hits is called the nucleus of the series.

Table 14 "A" ( $K_{1}$ No. 1, G.M.I.) gires the destructive effect of a collective fire with a single sight against a series of targets $1.80 \mathrm{~m}$. high and $20 \mathrm{~m}$. wide ; that is, against fifty men standing side by side. And also the effect of the same fire on a company column, the men standing; this is obtained by adding the depth of the column to the extent of the dangerous zone and counting the number of grazes which lie in this space.

Table 14 " $\mathrm{P}$ " (K, No. 2, G.MI.I.) gires the destructive effect of a collective fire with a single sight against a series of targets $45 \mathrm{cms}$. high and $20 \mathrm{~m}$. wide; that is, against fifty men lying down side by side, not under cover; and also the effect of the same fire on a company column lying down, this is obtained in the same way as described above.

Table 15 " $A$ " (No. 3, K, G.MI.I.) gives the effect of a collective fire with two sights against a target $1.80 \mathrm{~m}$. high and $20 \mathrm{~m}$. wide, i.e., against fifty men standing side by sicle.

Table 15 "B" (No. 4, $\mathrm{K}_{2}$, G.M.I.) gives the number of men's breadths $(0.40 \mathrm{~m}$.) struck by a collective fire with two sights; this is obtained by dividing, in the direction of the line of fire, the horizontal representation of the grazes into bands $0: 40 \mathrm{~m}$. wide, and then at each distance counting the 
number of bands which in a length equal to the dangerous zone at the distance have one or more grazes on them. For example, at $500 \mathrm{~m}$., when the $500 \mathrm{~m}$. and $600 \mathrm{~m}$. sights are combined thirty-four men's breadths are hit ; that is, on each of these men's breadths extending $65 \mathrm{~m}$. (equal to dangerous zone at $500 \mathrm{~m}$.) behind the target, there has been counted one or more grazes, with the same fire at $600 \mathrm{~m}$. forty-one men's breadths are hit.

\section{Obscriations on the Series obtained from the Use of One Sight.}

" $a$." The length of a series from the first term to the last represents the depth of what is called the "dangerous ground." See Plate XXV, Fig. 4.

"b." In the tables, the sum of any series does not represent the number of bullets that have struck the targets, as the same bullet may traverse several successive screens; for example, the bullet which grazes the top of the screen at $400 \mathrm{~m}$. will pass through the next seven screens, since the margin of the $400 \mathrm{~m}$. trajectory is $75 \mathrm{~m}$., and the screens are arranged at intervals of $10 \mathrm{~m}$. apart.

"c." The position of the nucleus of the shots of a series has been found to be about half the length of the "margin" in front of the target up to $700 \mathrm{~m}$.; this is caused by the aim being taken at the foot of the first target of the series. After $700 \mathrm{~m}$. the position of the nuclens corresponds practically with that of the object fired at ; this is due to the shading off of all objects at a distance, and the consequent unconscious tendency of the firer to aim more at the centre of his mark.

The "margins," or dangerous zones of the Mauser rifle, depending on a target $1.80 \mathrm{~m}$. high are as follows :-

$\begin{array}{llll}75 & \text { metres at } 400 & \text { metres. } \\ 65 & & 500 & \\ 48 & \prime & 600 & " \\ 38 & 7 & 700 & " \\ 32 & " & 800 & " \\ 25 & 900 & " \\ 20 & \Rightarrow & 1000 & \end{array}$

17 metres at 1100 metres.

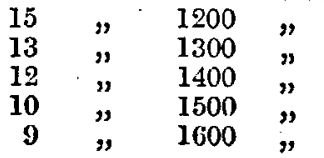

The position of the nuclei in front of the target as taken from the tables are :--

\begin{tabular}{|c|c|c|c|}
\hline 35 & & 400 & \\
\hline 30 & " & 500 & " \\
\hline 21 & ") & 600 & " \\
\hline 18 & $"$ & 700 & $n$ \\
\hline
\end{tabular}

By doubling the above numbers and comparing them with the extent of the dangerous zones at the same distances, it will be seen that the position of the nuclei in front of the object aimed at is practically one half of the extent of the dangerous zone.

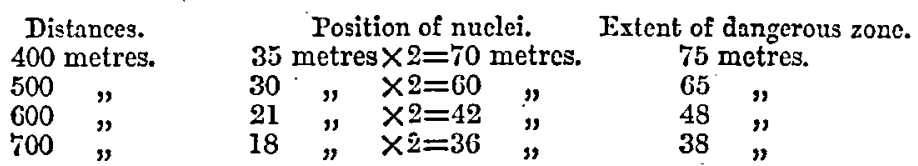

"d." The terms of the series in the sereral tables were obtained, as said before, by means of a large number of experiments; consequently the firingr of 100 rounds will not give exactly the same results; but the approximation will become closer as the number of rounds fired is increased. 'At the same time the length of the series will not vary considerably whether the number of rounds fired be either increased or diminished, provided the number is not

ruL. XXYII. 
reduced below fifty, which is the mininum number required to show cleariy the grouping of tlie hits.

"e." The term "the effective dangerous ground," sce Plate XXV, Jir. 4, has been applied to the space contained between the first imaginary screen of a series which has received ten hits, and the last which has reccived the same number. With the sight of $400 \mathrm{~m}$. when firing at the $1.80 \times 20 \mathrm{~m}$. target, this ground commences $140 \mathrm{~m}$. in front of the uucleus and ends $70 \mathrm{~m}$. behind it, and hence has an extent of $210 \mathrm{~m}$. In the same manner, with the sights of $500 \mathrm{~m}$. and $600 \mathrm{~m}$. its length is $200 \mathrm{~m}$. and $170 \mathrm{~m}$. respectirely. With the $800 \mathrm{~m}$. and the $1,000 \mathrm{~m}$. sight the effective dangerous ground is $110 \mathrm{~m}$. in extent. In the effective dangerous grounds from 400 to $900 \mathrm{in}$. at least one-tenth of the rounds fired are effective.

The following table extracted from the German Musketry Instruction of 28th September, 1875, is interesting from this point of view.

Table 16.

\begin{tabular}{|c|c|c|c|c|}
\hline \multirow[b]{2}{*}{ Sigbt. } & \multirow[b]{2}{*}{$\begin{array}{l}\text { Number of } \\
\text { rounds fired. }\end{array}$} & \multirow[b]{2}{*}{$\begin{array}{l}\text { Depth of } \\
\text { effective dan- } \\
\text { gerous ground. }\end{array}$} & \multicolumn{2}{|c|}{ Approximate number of hits } \\
\hline & & & $\begin{array}{l}\text { At the limits } \\
\text { of the cfictire } \\
\text { dangerous } \\
\text { ground. }\end{array}$ & At the nuclcus. \\
\hline $\begin{array}{r}\text { Mctres. } \\
100 \text { to } .600 \\
700 \text { to } 800 \\
900 \text { to } 1200 \\
1300 \text { to } 1600\end{array}$ & $\begin{array}{l}100 \\
100 \\
200 \\
300\end{array}$ & $\begin{array}{l}150 \\
100 \\
100 \\
100\end{array}$ & $\begin{array}{l}15 \\
10 \\
10 \\
10\end{array}$ & $\begin{array}{c}50 \text { to } 70 \\
30 \\
30 \text { to } 50 \\
\text { undetcrasinct. }\end{array}$ \\
\hline
\end{tabular}

"f." Errors in judging the distance must not exceed half of the extcint of the effective dangerous ground, otherwise only a few scattered shots would hit the mark; thus at $500 \mathrm{~m}$ an error of $100 \mathrm{~m}$. would throw almost all the shots of the object; and as here the probable error in judging the distance would be about $70 \mathrm{~m}$. it would not be advisable to use only one sight unless the distance were approximately lnomn; for this reason the German Instructions state that "bcyond $400 \mathrm{~m}$. the cmploynent of a single sight does not premise gocl results unless the mark is stationary, and there is the time and the means to regulate the fire, and finally unless the configuration of the grouid in front is not likely to diminish the effectiveness of the fire." "In all other cases, and especially against moving objects which adrance or retire, it is necessary to make use of two or more sights having a difference between them of $1 \mathrm{co} \mathrm{m}$."

\section{O'secrations on the Series obtained from the. Ute of Tro Sights.}

"a." The scries representing the effect of, a collective fire with two sights having a difierence of $180 . \mathrm{m}$. betreen them, have not been determined directly by experiment. Thus to find the terms of the combined series with the $600 \mathrm{~m}$. and $.700 \mathrm{~m}$. sights, it is necessary to add to the ter ms of the series with the $600 \mathrm{~m}$. sight, the terms of the series with the $700 \mathrm{~m}$. sight. Table 17 slows how this is effected.

"b." The effective dangerous ground when two sights are employed has a greater deptly than when only one sight is used, and this with an equal consumpion of awmunition. For example, if reference be nade to Table 17 it will bo

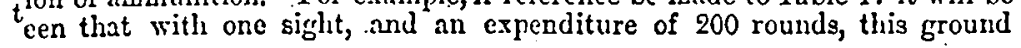


extends from $510 \mathrm{~m}$. with tweity-two hits to $690 \mathrm{~m}$. with ten lits ; that is to say, it has a total deptl of $180 \mathrm{~m}$. ; but if 200 rounds are fired with the combination of the 600 and $700 \mathrm{~m}$. sights, then the depth of the effective dangerous ground is extended to $260 \mathrm{~m}$.

The mingling of these two series is graphically shown in Plate XXV, Fig. 4.

In firing with two sights up to $700 \mathrm{~m}$.; and with three sights up to $1,200 \mathrm{~m}$., the extent of the ground swept by the bullets is such, that the effects of errors in judging distance, of atmospheric influences, and of those due to the bullets falling on sloping ground, are eliminated; and thus the shots can be grouped around the objective. Table 18 shows the grouping of shots when the 1,100, 1,200 , and $1,300 \mathrm{~m}$. sights are employed together, the effective dangerous ground will be seen to extend uninterruptedly from $1,090 \mathrm{~m}$. to $1,220 \mathrm{~m}$., and thence with three gaps to $1,300 \mathrm{~m}$. The total effectire depth may be taken as $130 \mathrm{~m}$., but the probable error in judging distance at $1,200 \mathrm{~m}$. amounts to $180 \mathrm{~m}$. Therefore, since the effective dangerous ground at any range should at least be double the amount of the probable error in judging distance at that range, the firing of 300 rounds under the above conditions would be ineffective so long as the distance from the objective was not accurately known. If twice 300 rounds were fired Table 18 shows that the effective dangerous ground would have a depth of $300 \mathrm{ml}$., extending from 1,010 to $1,340 \mathrm{~m}$, hence under these conditions, if a rough approximation of the distance could be obtained the fire would be effective, but if not known, it would be only partially effective. This reasouing applies, of course, to the Mauser rifle, but given a rifle with a flatter trajectory, causing consequently a greater dispersion of bullets at Iong ranges, then a combination of three sights would be effective at a considerable distance beyond $1,200 \mathrm{~m}$. The abore shows that in long-range firing the amount of ammunition required to produce the required effect must be carefully determined for.ench case as it arises; hence the decision as to the employment of this kind of fire must be retained in the hands of the senior Officers of the battalions.

Returning to the discussion of the use of two sights, it has been found that, as a rule, when firing 100 rounds, the number of hits on the screens does vary very much from the number made when only one sight is employed. Table 19 gives the percentage of hits when the 600 and $700 \mathrm{~m}$. sirghts are used together, and when only the $600 \mathrm{~m}$. sight is employed.

Before proceeding further it is advisable to obtain some iden, by means of experimental data, supplemented by theoretical deductions, of the rertical grouping of the hits, and of the shape of the gerbe in collective firing, in the same manner as the different trajectories rere analjzed in individual firing. It will be useful to compare the depth of the ground struck as calculated from the abore theoretical conditions, with its actual extent as derived from experimental firing, and thus to bring out the several reciprocal influences which determine the dispersion of the bullets.

\section{The Dimensions of the Shot Groups in Collectire Firing.}

The factors which govern the size of the shot groups in collective firing are, "a." Differences in the rifles. "b." Errors in aiming.

"a." Differcinces in the Rifles.-If a certain man tire 100 rounds, and make use of ten different Mrauser rifles, it has been found that the hits on the target lave a greater vertical extension than the major axes of the shot groujs as shown in Table 1, which are derired from the firing of the same man with the same rifle. This increase in vertical dispersion is due to differences in the construction of the rifles, and to differences in the treatment it has received while in the soldich's possession. In fact, in spite of the progress made in modern industry, it is impossible to obtain products perfectly identical to each other, and even if this were attainable, the

$$
3 \div 2
$$


different usages rifles are subjected to would, after a year or two, create differences which would influence the grouping of the shots on a target. Experience has shown that after the Mauser rifles have been in use two yenrs, an angular error in elevation of $0.333 \mathrm{~m}$. in $100 \mathrm{~m}$. has supervened; therefore in collective firing this addition lias to be made to the major axes shown in Table 1. For example, at $300 \mathrm{~m}$. the major axis would be $3 \times 333+0.58 \mathrm{~m}$. (the major axis in individnal firing at $300 \mathrm{~m}$.) or $1.58 \mathrm{~m}$.

"b." Errors in Alining.-If several men fire with different rifles it is found that the vertical ixis is greater than the one calculated as above, this is due to each nan making use of a differcnt amount of foresight; the difference between a full and a fine sight in the Mauser rifle has been found to cause an angular error in eleration of about twenty minutes. But experience has shown that men firing, even when making use of a rest in the lying down position, commit errors in aiming, of thirty minutes, this amount, therefore, must be added to that cuused by differences in the rifle. In consequence, in order to obtain the vertical axis of the short group at $400 \mathrm{~m}$., it is necessary to add to the dimensions given in Table 1 , viz, $0.84 \mathrm{~m}$., the maximum amount of error due to differences in the rifles, viz., $4 \times 333=1.333 \mathrm{~m}$.; the total $2.17 \mathrm{~m}$. gives the vertical dispersion due to the arm : to this must be added the proximate amount of personal errors in aiming, viz., $4 \times 873=3.49 \mathrm{~m}$. $(0.873 \mathrm{~m}$. being the value of the natural tangent of 30 minutes at $100 \mathrm{~m}$.), the grand total $2 \cdot 17+3 \cdot 49=5 \cdot 66$ is therefore the vertical axis of the shot group in collective fre at $400 \mathrm{~m}$. These calculations are made in Table 20.

There is no need to calculate the breadth of these shot groups, as it is assumed that the front under fire depends on the extension given to the troops firing.

In Table 20 is also given the mean trajectory of the $1,600 \mathrm{~m}$. sight extracted from Table $G_{3}$, G.M.I., and from this is calculated the upper and lower trajectory of the $1,600 \mathrm{~m}$. gerbe by means of the addition to, or subtraction from it, of lialf the height of the shot groups at the several distances as shown in column 5 of the same table. In a similar manner the trajectories of the gerbes of all the lines of sight from $400 \mathrm{~m}$. to $1,500 \mathrm{~m}$. can be calculated.

\section{The Depth of the Ground struck and of the Dangerous Ground as obtained by Calcuiation, compared with the Results derived from Experimental Firing.}

The distinction between the terms dangerous zone and dangerous ground will be more clearly understood if reference is made to Diagram 5 ; in which the track of a gerbe, from its lower edge first tonching a 6 -foot target to its upper trajectory neeting the ground, is clearly indicnted. This diagram, with regard to the "zone swept by the entire gerbe," applies chiefly to individual fire as beyond $600 \mathrm{~m}$., the height of the shot groups exceeds that of the target.

Looking at Plate XXV, Firg. 5 , and imagining that the line $\mathrm{T}_{1} \mathrm{G}_{1}$ is a straight line, then the angle $T_{1} G_{1} T$ represents the angle of the drop of the bullet; and since $T_{1} T$ equals half the depth of the gerbe at the extreme range of the sight used, and $\mathrm{TG}_{1}$ equals half the extent of the ground struck : then the extent of the ground struck is equal to the vertical height of the shot group, corresponding to the distance of the sight employed, divided by the tangent of the angle of the drop at the same distance. For example, with the $900 \mathrm{~m}$. gerbe the vertical height of the shot group at this distance is from Table 20 , $14.03 \mathrm{~m}$; the angle of drop is $4^{\circ} 20^{\prime}$, and its tangent is 07578 , consequently the extent of ground struck is $\frac{14.63}{.07578}$, or $193 \mathrm{~m}$.

In Table 21 these calculations are made for all distances between 400 and $1,400 \mathrm{~m}$.

If to the length of the ground struck is added the depth of the dangerous 
zone, the extent of the dangerons ground is obtained. The depths of these "dangerous grounds" thius calculated are inserted in. column 6 of Table 21, and by their side, in column 7 , are placed the extent of the several dangerous grounds extracted fiom Table 14, " $A, "$ and obtained from direct experiment. The small differences which exist between the results obtained by either method, prove the correctness of the considerations which have formed the basis of the calculations. The mean depth of the dangerous ground as obtained by calculation is $226.8 \mathrm{~m}$, and $228 \mathrm{~m}$. as obtained from experimental firing, the average difference between these amounts being only $1.40 \mathrm{~m}$.

\section{The Reciprocal Action of the Causes uchich produce the Dispersion of the Shots.}

If Table 20 be examined it will be seen that up to $1,000 \mathrm{~m}$. the vertical dispersion due to errors in aiming exceeds the vertical dispersion due to the Mauser rifle, and that from 1,000 m. to $1,600 \mathrm{~m}$. the reverse takes place. This shows that in estimating the value of different riffes it is not only necessary to compare the flatness of their trajectories and the acenracy of their shooting, but it is also necessary to compare the extent of the spread of the bullets when a dozen or more different rifles of the same pattern are made use of in collective fire. The pattern of rifle which, under these circumstances, gives rise to a denser and a more regular grouping of hits will be the best, and have the most destructive effect in the field. There is no nethod more searching for testing the value of different patterns of rifles than the rigid comparison of the series of terms obtained from long-continued collectire firing.

\section{Jodlification in the Series when the Conditions of the Firing are changed.}

If the men, though still firing from a rest, are less skilful, and make errors in elevation in excess of $33^{\prime}$, the series will be lengthened, and the shots in the nucleus and in the adjoining screens will be less dense, and, further, the series will be less regular in character. By employing men still less skilful in firing all these irregularities will be accentuated, and it may happen that gaps will appear in the series in the neighbourhood of the distance corresponding to the sight in use.

When the firing takes place without rests the series is much lengthened and becomes irregular; the destructive effect of the gerbe ceasing in some places. These gaps are more numerous and nearer the distance corresponding to the sight in use in proportion as the inaccuracy of the firing increases. This proves the incorrectness of the statement, that collective fire is the negation of all musketry instruction. On the contrary, representative series slow, by the modifications they undergo when deduced from the firing of bad shots, that the drilling and careful instruction of the soldier carries as much weight and has as much influence on collective fire as it has on individual fire. The skill of the frers is so much the greater as the record of their shooting gives a more regular, more continuous, and denser series. From this it follows that the collective fire of several men at a single target at distances over $400 \mathrm{~m}$. is not the true gauge of their efticiency. It is necessary that they fire at a series of screens, which will register all the hits; then from their density an estimate of the ralue of their shooting can be obtained. 'The position of the nucleus offers no clue, as it does not depend on the efforts of the men, but on factors beyoud their control.

Atmospheric conditions lave their influence on firing; thus, temperature lower than $3^{\circ} \mathrm{C}$. (the sight of the Mauser rifle is adjusted to $25^{\circ} \mathrm{C}$.) would cause the series to be less dense than the normal one, while the series would become denser if the temperature rose above $3^{2}$; not taking into account, of course, the hygrometric state of the air. An atmosphere more or less warm lias the effect of advancing or retiring a whole series with reference to its normal position. Between $-3^{2}$ and $+3^{\circ}$ a fall of one degree displaces the 
series towards the firing point; about $4 \mathrm{~m}$. at $100 \mathrm{~m} ., 8 \mathrm{~m}$. between 200 and $300 \mathrm{~m}$., and $12 \mathrm{~m}$. between 400 and $1,200 \mathrm{~m}$. On the other hand, each rise of one degree between $3^{\circ}$ and $16^{\circ}$ removes the series further back: $2 \mathrm{~m}$. between 0 and $300 \mathrm{~m}$., and $4 \mathrm{~m}$. between 400 and $1,200 \mathrm{~m}$.

The deviations in the range of the bullets, due to the infiuence of temperature, are similar to the deviations due to errors in aiming, nearly constant, and diminish instead of increasing at distances beyond $1,200 \mathrm{~m}$. The hygrometric state of the air sometimes counterbalances this increase of range, as it has been found that, when the ground is much heated by the sun, the most densely saturated layer of air is at a certain distance above the ground ; and, consequently, acts as a retarding force more powerfully on the high trajectories than on the lower ones. With a temperature of $15^{\circ} \mathrm{C}$. $\left(58^{\circ} 5^{\circ}\right.$ F.) the shot groups of the Mauser rifle will be displaced $48 \mathrm{~m}$. awny. from the firing point, if the firing is at 400 yards. But as at this distance aiming at the foot of the target lias the effect of bringing the nucleus $35 \mathrm{~m}$. towards the firing point, the deviation in range caused by an elevation in temperature, approximating to the mean temperature of Central Europe, is compensated up to $700 \mathrm{~m}$. by the practice of aiming at the foot of an object.

\section{Modifications caused in the Serics by the Ground on which the Objectice rests, rising or falling vith reference to the Line of Sight.}

The next point to consider is, how the dispersion of the bullets is affected by the slope of the ground on which they fall. Mathematical proof need not be given to show that when ground rises with reference to the line of sight, the extent of the ground struck is dininished, and that the contrary takes place when the ground falls; nor to prove the corollary that the density of the hits is increased in the first case and diminished in the second.

Still the length of the dangerous ground under all circumstances requires to be known, and therefore the following calculations must be made :- Let $G$ represent the vertical axis of the shot group in collective firing at any selected distance, $a$ the angle of the normal drop of the bullet at this same distance, and $a^{\prime}$ the angle of the actual drop of the bullet on a surface inclined with referenee to the line of sight; let $x$ equal the interval which must exist between the terms of the new series-bearing in mind that the intervals in the normal series are 10 metres-and $n$ represent the number of terms in each series; then, since the extent of the dangerous ground is equal to the depth of the ground struck, added to the depth of the dangerous zone, the following equations are arrived at :-

$$
\begin{gathered}
10 n=\frac{\mathrm{G}}{\operatorname{Tan} a}+\frac{1 \cdot 8^{\circ}}{\operatorname{Tan} a}=\frac{\mathrm{G}+1 \cdot 8^{\circ}}{\operatorname{Tin} a} \\
n x=\frac{\mathrm{G}}{\operatorname{Tan} a^{\prime}}+\frac{1 \cdot 8^{\circ}}{\operatorname{Tan} a^{\prime}}=\frac{\mathrm{G}+1 \cdot 8^{\circ}}{\operatorname{Tan} a^{\prime}} \\
\text { for } \frac{\mathrm{G}}{\operatorname{Tan} a}=\text { and } \frac{\mathrm{G}}{\operatorname{Tan} a^{\prime}} \text { represent the ground struck } \\
\text { and } \frac{1 \cdot 8^{\circ}}{\operatorname{Tan} a} \text { and } \frac{1 \cdot 8^{\circ}}{\operatorname{Tan} a^{\prime}} \text { the extent of the dangerous zone. } \\
\text { then } \frac{x}{10}=\frac{\operatorname{Tan} a}{\operatorname{Tan} a^{\prime}} \text { and } x=\frac{10 \operatorname{Tan} a}{\operatorname{Tan} a^{\prime}}
\end{gathered}
$$

Substituting the value of $x$ for the $10 \mathrm{~m}$. in the normal series and multiplying by the uumber of terms in the same series, the extent of the dangerous 
ground can be obtained for all slopes and at all distances. The preceding calculatious must not be thought to be applicable on the field of battle where tactical considerations are dominant, but still they serve their purpose by pointing out how the slopes of ground affect the destructive action of collective fire, and from this information serviceable tactical rules can be deduced.

In Table 22 the reduction in length of the normal $10 \mathrm{~m}$. intervals are shown for distances between 400 and $1,600 \mathrm{~m}$., and when the ground rises respectively $3^{3}, 5^{\circ}$, or $10^{\circ}$. The following examples will show how the calculations have been made.

Example.-Find the length of the interval which separates the different terms of the $400 \mathrm{~m}$. line of sight when firing at an object on an ascending slope of $3^{3}$.

In Appendix $\mathrm{G}_{3}, \mathrm{G} . \mathrm{M}$.I. of 1877 , the normal angle of the drop of a bullet at $400 \mathrm{~m}$. is stated to be $1^{\circ} 8^{\prime} 16^{\prime \prime}$; for all prictical purposes $1^{\circ} 10^{\prime}$ is sufliciently near. The actual angle of the drop of a bullet when the ground on which the bullet falls rises with reference to the line of sight is equai to the normal angle of drop added to the angle wlich the slope of the ground makes with the line of sight; and when the ground falls, to the normal angle of drop diminished by the angle formed by the slope of the ground and the line of sight. Applying the above data and calling $x$ the reduced interval required, we have from the preceding equation-

$$
\begin{aligned}
& \frac{x}{10}=\frac{\operatorname{Tan} 1^{\circ} 10^{\prime}}{\operatorname{Tan} 4^{\circ} 10^{\prime}}=\frac{.02037}{.07286} \\
& \text { and } x=\frac{\cdot 2037}{.07286^{\circ}}=3 \mathrm{~m} \text {. }
\end{aligned}
$$

If Table 22 be examined, it will be seen that when firing at an object on an ascending slope, the normal extent of the dangerous ground, and in consequence the extent of the ground struck by all the bullets in the gerbe, is diminished by one-half; at $800 \mathrm{~m}$, when the slope is $5^{\circ}$, at $1,000 \mathrm{~m}$. when the slope is $5^{\circ}$, and at $1,500 \mathrm{~m}$. when it is $10^{\circ}$.

\section{Depth of the Effective Dangerous Ground when the Surface on which the Bullets fall is not parallel to the line of Sight.}

It has been said before that when the value of the interval of a series derived-from collective fire at an object on a slope has been obtained, it is easy to calculate the corresponding extent of the effective dangerous ground, but an example may make this clearer.

Example. Find the length of the dangerous ground at $600 \mathrm{~m}$. when the ground which receives the bullets makes an ascending angle of $5^{\circ}$ with the line of sight. Referring to Table 14, "A," it will be seen that the extent of the normal efiective dangerous ground with the $600 \mathrm{~m}$. sight is $170 \mathrm{~m}$, and that it contains serenteen terms. Looking at Table 22, the length of each term of the series with the $600 \mathrm{~m}$. sight, when employed against a slope of $5^{\circ}$, will be found to be $3 \mathrm{~m}$.; consequently the effective dangerous ground is $17 \times 3$ or $51 \mathrm{~m}$. ; thus the effect of firing against a slope of $5^{\circ}$ is at $700 \mathrm{~m}$. to reduce the effective dangerous ground from $170 \mathrm{~m}$. to $51 \mathrm{~m}$.

Table 23 contrasts the extent of the effective dangerous ground when fire is directed on an ascending slope with its extent when the fire takes place on a plane. It may be observed that the mean length of the effective dangerous ground at distances between $400 \mathrm{~m}$. and $1,400 \mathrm{~m}$. is $131 \mathrm{~m}$, and that for the slopes of $3^{\circ}, 5^{\circ}, 10^{\circ}$, its mean length is reduced respectively to 70,54 , and $30 \mathrm{~m}$; in other words, when fire is directed at ascending slopes forming angles of $3^{\circ}$, $5^{\circ}$, or $10^{\circ}$ with the line of sight, the effective dangerous ground is approximately one-half, one-third, or one-fourth the length of the effective dangerous 
ground under normal circumstances; and, similarly, when the bullets fall on descending slopes, making angles of $3^{3}, 5^{\circ}$, or $10^{\circ}$ with the line of sight, the extent of the effective dangerous ground is approxinately double, treble, or quadruple the length of the normal effective dangerous ground.

\section{Tactical Considerations.}

Before concluding it may be pointed ont how the foregoing study may be utilized with reference to tactical questions; for instance, the length of the dangerous ground in the different series serves to determine the distances which should separate the different échelons during an attack or when on the defensive. It is clear that the placing two lines under the influence of same gerbe is to be aroided whenever it is possible; but since the extent of the dangerous ground increases the nearer the enemy is approached, the paradox is arrived at, that the nearer the front line is to the enemy the further the supports should be from it. This difficulty is met by placing as many rifles as possible in the front line of the attack from its very commencement, and by keeping the supports about 500 yards in rear, and thus clear of the fire directed at the front line. Under these circumstances, the strong front line would be able to push rapidly and emergetically forward until checked by some serions opposition. During this halt, and while preparing for a further advance by trying to dominate the enemy's fire, the front line would be strong enough, if a counter-attack were made, to hold it in check sufficiently long to give time for the supports to come up. The supports, if not thus required, would remain outside the influence of the fire aimed at the front line until the losses in it necessitated its being reinforced.

Again, a study of the series helps to show the relative amount of losses due to different formations at different periods of an action. Thus in the German Musketry Instructions it is stated, that a standing company column up to $700 \mathrm{~m}$. suffers little more loss than a line, but beyond this distance, and up to $1,600 \mathrm{~m}$., its losses are more than double those of a line; while a company column lying down must expect losses double or treble those of a line lying down.

A consideration of the data connected with the influence of slopes on the dispersion of bullets, leads to the conclusion, that when the ground on which the objective rests, makes an ascending angle of over $3^{\circ}$ with the line of sight, it is advisable to make use of a combination of trro sights, and to employ three sights, if the slopes be steeper still. Whereas, if the ground slopes away from the line of sight, one sight only should be made use of.

The study of the blending of gerbes when two or more sights are made use of leads to the impression that a single line of men cannot give full effect to the deadly power of long-ranging rife-fire; hence arises the idea of double tier fire, or the firing of one line of men over the heads of another line at the same object : possibly to be realized on the defensive on some prominent spur commanding and flanking the enemy's line of approach; possibly, if time admits, in a skilful arrangement of shelter trenches, and, lastly, to be carried out in earthworks intended to act as supports in a position, or as an outer line of defence around some important village or town.

Before quitting this part of the subject a few words must be said as to the method of employing collective fire in the field. Looking at its mode of action, viz, the simultaneous discharge of many rifles at the same object, its effect may be likened to that of a blow; hence, like a blow, it must be delivered with rapidity; the number of rounds allotted to it must be discharged at the same time; a pause would then take place, the smoke would be allowed to clear off, the men's nerves would become stendied, and then, if required, another blow could be struck; or, a certain number of blows might be given rapidly, one after the other. The suddenness with which such fire 
would be delivered, and its intermittent nature, would hare a moral effect on the enemy ; it would create a feeling of suspeuse, and prevent the nerves of the men getting accustomed to the ping of the bullets. Further, as collective fire should not be carried out by a less number of nen than 100, its employment, as a rule, should be directed by a battalion commander; and in his hands it is probable that no wiste of ammunition would be permitted, as the objective would be well selected, its distance fairly estimated, and the result of the fire carefully studied.

\section{Conclusion.}

Having travelled over many paths, branching one from the other, it may be well, in corrclusion, briefly to summarize what are the salient features connected with the combination of two or more siglits in collective fire. The advantages claimed for this system of fring at all distances beyond the limits of individual fire, fixed at $400 \mathrm{~m}$. for the Mrauser rifle, are-that it counterbalances the loss of effect in rille-fire due to moving objectives, errors in judging distances, deviations caused by atmospheric influences, and the shortening of the dangerous ground resulting from the surface on which the bullets fall not being parallel to the line of sight. The mere statement of these facts brings at once to mind the number of situations in war where the employment of this kind of fire would have a marked influence on the fortunes of the day; and no more important tactical problem awaits the test of practical experience than that of how lest to utilize collective fire on the field. The plan must be thought out in pence-tirne, and practised in war; not to make use of the full power of the infantry rifle is like asking a man to defend himself with one hand tied behind his back. Whatever power is latent in rifle-fire must be drawn out, and no impediment should be placed in the way of obtaining the necessary data on which to formulate a decision.

And now, at the conclusion of this paper, as at its commencement, my indebtedness to the articles in the "Revue MIilitaire le l'Etranger," on the German Musketry Instructions, must again be acknowledged; tables have been bodily extracted from them, entire paragraphs have been copiously used, and arguments and deductions freely borrowed. Thus my paper lays no claim to originality, but is merely a critical collection and arrangement of data connected with rifle-fire; useful perchance at this time, when all officers are studying the theory as well as the practice of musketry. 
Table 1.

Dimensions of the shot groups of the Mauser rife.

\begin{tabular}{|c|c|c|c|c|}
\hline 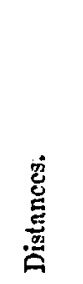 & 离 & & 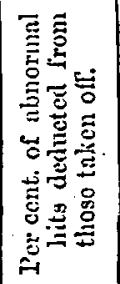 & Remarks. \\
\hline $\begin{array}{l}\mathrm{m} . \\
100\end{array}$ & $\begin{array}{l}\mathrm{m} . \\
0 \cdot 16\end{array}$ & $\mathrm{~m}$. & per cent. & \\
\hline 150 & $0 \cdot 2 \cdot 1$ & $0 \cdot 24$ & 2 & 'The size of a man's head. \\
\hline 200 & $0 \cdot 3 \cdot 4$ & $0 \cdot 32$ & 3 & \\
\hline 250 & $0 \cdot 1.1$ & $0 \cdot 40$ & 4 & The breadth of a man. \\
\hline 300 & $0 \cdot 58$ & $0 \cdot 49$ & 5 & A little broader than a mau. \\
\hline $\mathbf{8 5 0}$ & $0 \cdot 68$ & $0 \cdot 58$ & 6 & \\
\hline 400 & $0 \cdot 51$ & 0.63 & 7 & \\
\hline 500 & $1 \cdot 18$ & 0.06 & 8 & A little brosder than a group of two men. \\
\hline 600 & $1 \cdot 5 S$ & $1 \cdot 26$ & 9 & Tho heiglt of a $\tilde{5} \mathrm{ft} .3 \mathrm{in}$. standing man. \\
\hline 700 & $2 \cdot 12$ & $1 \cdot 63$ & 10 . & \\
\hline 800 & $2 \cdot 80$ & $2 \cdot 12$ & 11 & \\
\hline 900 & $3 \cdot 78$ & $2 \cdot 61$ & 12 & $\begin{array}{l}\text { ALore than trice the height and six times } \\
\text { the breadth of a standing man. }\end{array}$ \\
\hline 1000 & $4 \cdot 7 \cdot 4$ & $3 \cdot 2 \cdot 1$ & 13 & \\
\hline 1100 & $6 \cdot 0(i$ & $3 \cdot 83$ & 14 & \\
\hline 1200 & $7 \cdot 60$ & $4 \cdot 60$ & 15 & \\
\hline 1300 & $9 \cdot 64$ & $5 \cdot 34$ & 16 & \\
\hline 1.100 & $12 \cdot 12$ & $6 \cdot 18$ & 17 & \\
\hline 1500 & $15 \cdot 12$ & $6 \cdot 96$ & 18 & $\begin{array}{l}\text { It is necessary to place eight targets } 1.8 \mathrm{~m} \text {. } \\
\text { high and } 69 \mathrm{~m} \text {. wide at } 10 \mathrm{~m} \text {. from } \\
\text { cach other in order to intercept } 82 \text { per } \\
\text { cent. of the hits. }\end{array}$ \\
\hline 1600 & $18 \cdot 72$ & $78 \cdot 6$ & 10 & $\begin{array}{l}\text { It is necessary to place ten targets } 1.80 \mathrm{~m} \text {. } \\
\text { high and } 7.86 \mathrm{~m} \text {. wide at } 9 \text { m. apart in } \\
\text { order to intercept } 81 \text { per cent. of the hits. }\end{array}$ \\
\hline
\end{tabular}


THE UTILIZATION OF RIFLE FIRE IN THE FIELD.

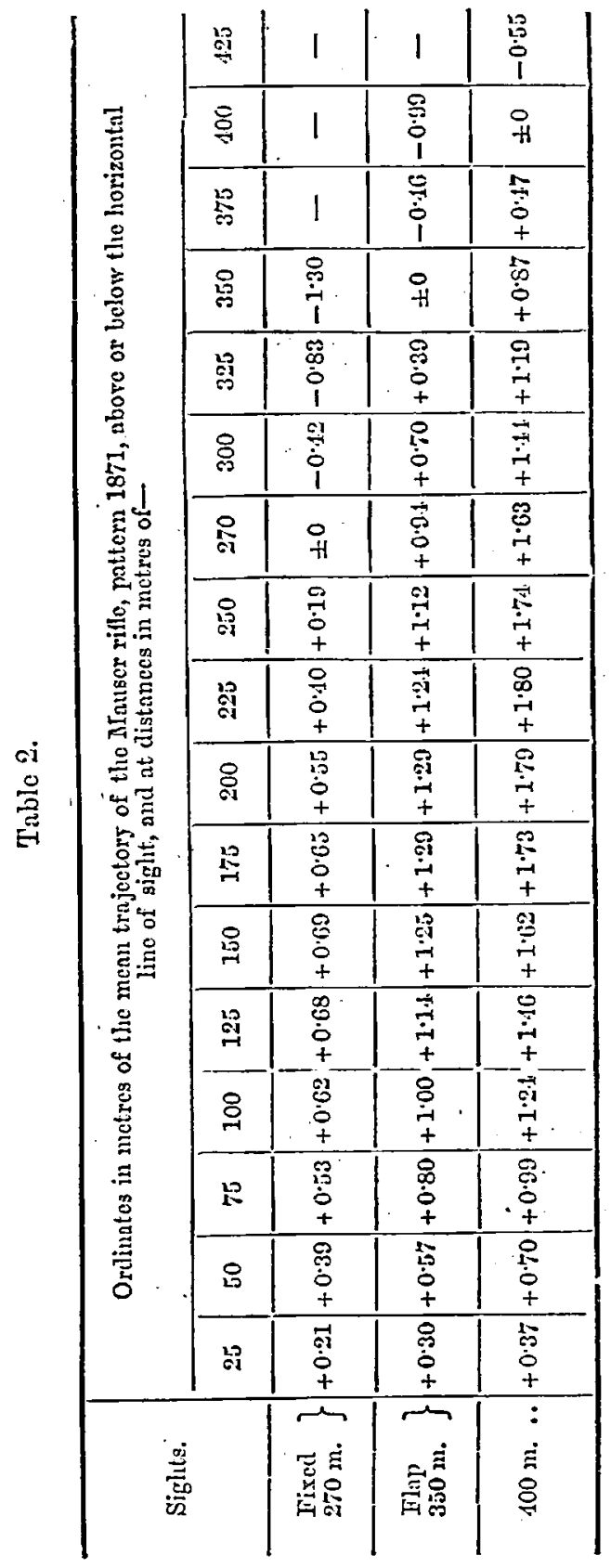


Table 3.

Ordinates of the upper and lower trajectories of the $350 \mathrm{~m}$. gerbo abore a horjzontal plane, or one sensibly parallel to the line of sight, according as the firer is standing, knceling, or lying down, and aim taken at the foot or centre of the target at the sereral distances named below.

\begin{tabular}{|c|c|c|c|c|c|c|c|c|}
\hline \multirow{2}{*}{ Distances. } & \multicolumn{4}{|c|}{ Upper trajectory. } & \multicolumn{4}{|c|}{ Lower trajectory. } \\
\hline & $\begin{array}{l}\text { Foo } \\
\text { to }\end{array}$ & $\begin{array}{l}\text { of the } \\
\text { jet. }\end{array}$ & $\begin{array}{r}\text { Centr } \\
\text { tar }\end{array}$ & $\begin{array}{l}\text { of the } \\
\text { set. }\end{array}$ & $\begin{array}{l}\text { Foot } \\
\text { tar }\end{array}$ & $\begin{array}{l}\text { of the } \\
\text { get. }\end{array}$ & $\begin{array}{r}\text { Centre } \\
\text { tar }\end{array}$ & of the \\
\hline $\begin{array}{c}\text { AIetres. } \\
50 . . \ldots \ldots \ldots \ldots\end{array}$ & $\stackrel{\mathrm{n}}{\mathrm{o}}$ & c. & $\underset{1}{m}$ & c. & m. & $\begin{array}{l}\text { c. } \\
\mathbf{5 3}\end{array}$ & $\mathbf{m}$. & $\begin{array}{r}c . \\
43\end{array}$ \\
\hline $100 . \ldots \ldots \ldots$ & 1 & 08 & 1 & 93 & 0 & 92 & 1 & 82 \\
\hline $150 \ldots \ldots \ldots \ldots$ & 1 & 37 & 2 & 20 & 1 & 13 & 2 & 03 \\
\hline $200 \ldots \ldots \ldots \ldots$ & 1 & 46 & 2 & 36 & 1 & 12 & 2 & 02 \\
\hline $250 \ldots \ldots \ldots \ldots$ & 1 & 34 & . 2 & 21 & 0 & 90 & 1 & 80 \\
\hline $300 \ldots \ldots \ldots \ldots$ & 0 & 99 & 1 & 89 & 0 & 41 & 1 & 31 \\
\hline $350 \ldots \ldots \ldots \ldots$ & 0 & 31 & 1 & $2 \cdot 1$ & 0 & 31 & 0 & 56 \\
\hline
\end{tabular}

Table 4.

Ordinates, at interrals of $50 \mathrm{~m}$. above a horizontal plane, of the $350 \mathrm{~m}$. Jine of sight, according as the firer is standing, kneeling, or lying down, and uim taken at the foot or centre of the target.

\begin{tabular}{|c|c|c|c|c|c|c|}
\hline \multirow{3}{*}{$\begin{array}{l}\text { Distances } \\
\text { corresponding } \\
\text { to the } \\
\text { ordinates. }\end{array}$} & \multicolumn{3}{|c|}{$\begin{array}{l}\text { Aim directed at the foot of } \\
\text { target at } 350 \mathrm{~m} .\end{array}$} & \multicolumn{3}{|c|}{$\begin{array}{c}\text { Ain directed at the centre of } \\
\text { a target at } 350 \mathrm{~m} .\end{array}$} \\
\hline & \multicolumn{3}{|c|}{ Firing. } & \multicolumn{3}{|c|}{ Firing. } \\
\hline & Standing. & Kneeling. & $\begin{array}{l}\text { Tying } \\
\text { down. }\end{array}$ & Standing. & K'neeling. & $\begin{array}{l}\text { Lring } \\
\text { down. }\end{array}$ \\
\hline $\begin{array}{l}\text { Metres. } \\
\quad . .\end{array}$ & $\begin{array}{ll}\mathrm{m} . & \mathrm{c} . \\
1 & 50\end{array}$ & $\begin{array}{ll}\text { m. } & \text { c. } \\
0 & \text { oo }\end{array}$ & $\begin{array}{cl}\text { m. } & \text { c. } \\
0 & 30\end{array}$ & $\begin{array}{ll}\mathrm{m} . & \mathrm{c} . \\
\mathrm{I} & 50\end{array}$ & $\begin{array}{cc}\mathrm{m} . & \text { c. } \\
0 & \mathbf{0 0}\end{array}$ & $\begin{array}{cc}\text { m. } & \text { c. } \\
0 & 30\end{array}$ \\
\hline $50 \ldots \ldots \ldots \ldots$ & I 23 & 077 & 025 & 140 & $0 \quad 90$ & $0 \quad 38$ \\
\hline $100 \ldots \ldots \ldots \ldots$ & 107 & 064 & $0 \quad 21$ & 132 & 090 & $0 \quad 47$ \\
\hline $150 \ldots \ldots \ldots \ldots$ & 085 & $0 \quad 51$ & 017 & 124 & $0 \quad 90$ & $0 \quad 55$ \\
\hline $200 \ldots \ldots \ldots \ldots$ & $0 \quad 6: 1$ & $0 \quad 38$ & $0 \quad 12$ & 114 & $0 \quad 90$ & $0 \quad 64$ \\
\hline $250 \ldots \ldots \ldots \ldots$ & 042 & 025 & o $\quad 08$ & 106 & 090 & $0 \quad 73$ \\
\hline $300 \ldots \ldots \ldots \ldots$ & $0 \quad 21$ & $0 \quad 12$ & $\begin{array}{ll}0 & 0.1\end{array}$ & $0 \quad 93$ & 090 & 081 \\
\hline 350. & $\bullet$ & $\cdots$ & $\cdots$ & 090 & $0 \quad 00$ & $0 \quad 90$ \\
\hline
\end{tabular}


THE UTILIZATION OF RIFLE FIRE IN THE FIELD.

827

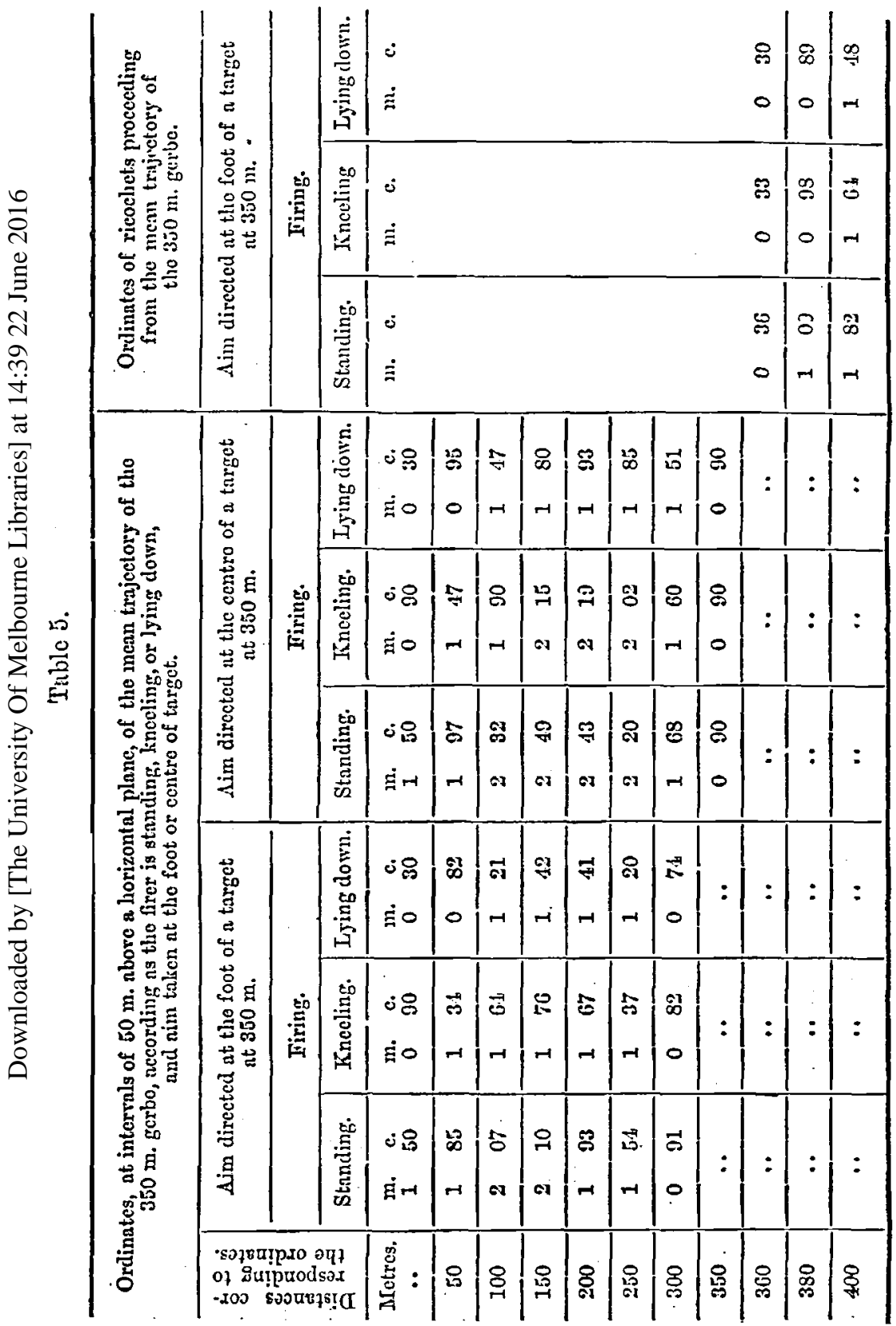


THE UTILIZATION OF RIFLE FIRE IN THE FIELD.

\begin{tabular}{|c|c|c|c|c|c|c|c|c|c|c|c|c|c|c|}
\hline \multirow{3}{*}{ 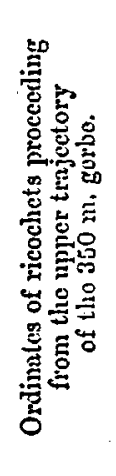 } & \multirow{3}{*}{ 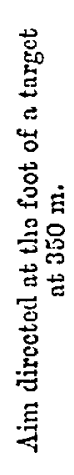 } & \multirow{3}{*}{ 荵 } & 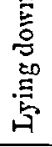 & \multicolumn{9}{|l|}{$\dot{\sharp}$} & 0 & $\begin{array}{l}0 \\
0\end{array}$ \\
\hline & & & 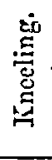 & \multicolumn{9}{|l|}{ ن } & $\begin{array}{l}\vec{a} \\
0\end{array}$ & $\begin{array}{l}\tilde{\%} \\
0\end{array}$ \\
\hline & & & 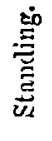 & & 0 & ${ }^{8}$ \\
\hline \multirow{7}{*}{ 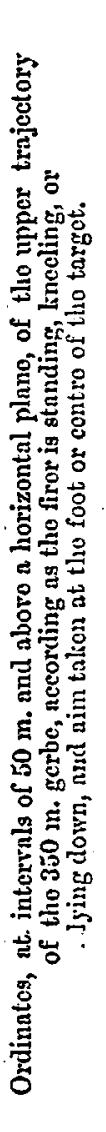 } & \multirow{3}{*}{ 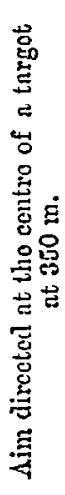 } & \multirow{3}{*}{ 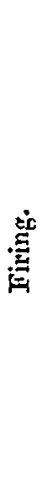 } & 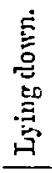 & 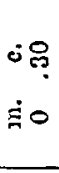 & $\begin{array}{l}8 \\
0\end{array}$ & $\rightarrow$ & $\begin{array}{l}\text { 엉 } \\
-1\end{array}$ & 03 & $\begin{array}{l}5 \\
0 \\
01\end{array}$ & $\begin{array}{l}\infty \\
-1\end{array}$ & $\begin{array}{l}\vec{n} \\
\vec{i}\end{array}$ & : & : & : \\
\hline & & & 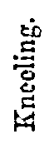 & $\begin{array}{l}\text { ¿\& } \\
\text { घं }\end{array}$ & $\begin{array}{l}\overrightarrow{25} \\
\rightarrow\end{array}$ & $\rightarrow$ & $\begin{array}{l}\text { ले } \\
\text { oi }\end{array}$ & ఝ & $\overrightarrow{a t}$ & $\begin{array}{l}\infty \\
-1\end{array}$ & $\vec{a}$ & : & : & : \\
\hline & & & 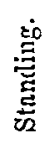 & $\begin{array}{l}\text { io } \\
\dot{\Xi}\end{array}$ & $\begin{array}{l}\vec{\sigma} \\
01\end{array}$ & 웅 & $\begin{array}{l}\overrightarrow{0} \\
01\end{array}$ & ه & a1 & $\begin{array}{l}5 \\
-1\end{array}$ & $\begin{array}{l}\overrightarrow{a i} \\
\rightarrow\end{array}$ & : & : & : \\
\hline & \multirow{3}{*}{ 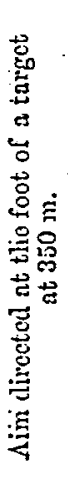 } & \multirow{3}{*}{ 它 } & 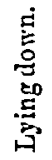 & $\begin{array}{l}ن \circ \\
\vdots 0\end{array}$ & 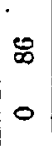 & H & $\left\{\begin{array}{l}\overrightarrow{3} \\
-i\end{array}\right.$ & $\begin{array}{l}\text { D } \\
\rightarrow \\
\rightarrow\end{array}$ & 완 & $\begin{array}{l}g \\
-1\end{array}$ & $\begin{array}{l}\overrightarrow{0} \\
0\end{array}$ & $\stackrel{\infty}{\sim}$ & : & : \\
\hline & & & 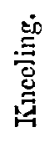 & $\begin{array}{l}\circ 8 \\
\vdots 0\end{array}$ & $\begin{array}{l}\infty \\
\boldsymbol{\infty} \\
-1\end{array}$ & I & $\begin{array}{l}\infty \\
\infty \\
-i\end{array}$ & $\vec{\infty}$ & 8 & $\begin{array}{l}\exists \\
\Rightarrow\end{array}$ & $\vec{m}$ & P् & : & : \\
\hline & & & 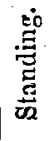 & $\begin{array}{l}ن 0 \\
\dot{8}-1\end{array}$ & $\begin{array}{l}8 \\
-1\end{array}$ & $\begin{array}{l}39 \\
9 \\
9\end{array}$ & $\begin{array}{l}g 7 \\
\text { gi }\end{array}$ & $\begin{array}{l}\circ \\
\sim\end{array}$ & 80 & $\begin{array}{l}81 \\
-1\end{array}$ & $\begin{array}{l}\overrightarrow{0} \\
0\end{array}$ & $\begin{array}{l}F \\
0\end{array}$ & & \\
\hline & 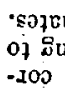 & & & : & 80 & $\stackrel{8}{8}$ & 号 & ్ㅗㅇ & 号 & ৪্ & 号 & క్లి & :్లో & $\stackrel{8}{\circ}$ \\
\hline
\end{tabular}


THE UTHIZATION OF RIFLE FIRE IN TIE FIELD. 829

\begin{tabular}{|c|c|c|c|c|c|c|c|c|c|c|c|c|c|c|}
\hline \multirow{3}{*}{ 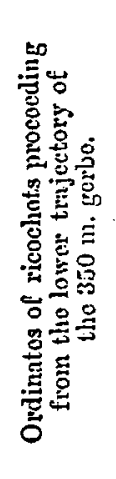 } & \multirow{3}{*}{ 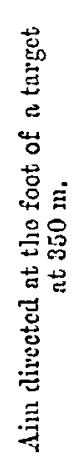 } & \multirow{3}{*}{ 离 } & 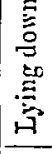 & \multicolumn{7}{|l|}{$\Xi$} & 8 & 0 & 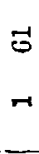 & $\begin{array}{l}81 \\
\text { of }\end{array}$ \\
\hline & & & 它 & \multicolumn{7}{|l|}{$\Xi$} & 0 & -1 & $\begin{array}{l}8 \\
\rightarrow\end{array}$ & $\mid$ \\
\hline & & & 它 & \multicolumn{5}{|l|}{$\dot{\Xi}$} & \multicolumn{3}{|c|}{$\begin{array}{l}8 \\
0 \\
0\end{array}$} & 8 & $\vec{\infty}$ & $\left\{\begin{array}{l}05 \\
0\end{array}\right.$ \\
\hline \multirow{7}{*}{ 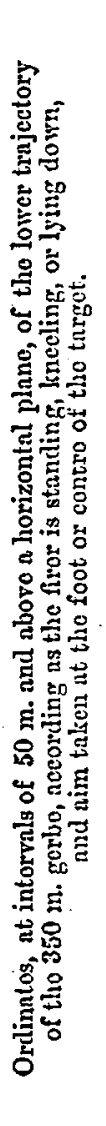 } & \multirow{3}{*}{ 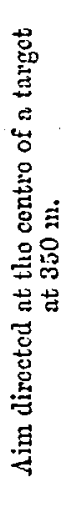 } & \multirow{3}{*}{ 莡 } & 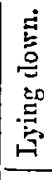 & $\begin{array}{l}\text { نP } \\
\text { : } 0\end{array}$ & 0 & $\vec{?}$ & $\begin{array}{l}\infty \\
-1 \\
-1\end{array}$ & & $\begin{array}{l}\tilde{S} \\
-1\end{array}$ & $\begin{array}{l}91 \\
-1\end{array}$ & 0 & : & : & : \\
\hline & & & 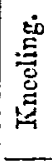 & $\begin{array}{l}\text { ¿g. } \\
\text { झం }\end{array}$ & $\begin{array}{l}\mathscr{P} \\
\sim \\
\sim\end{array}$ & D. & $\begin{array}{l}8 \\
0 \\
0\end{array}$ & $\begin{array}{l}\text { 昘 } \\
\text { कs }\end{array}$ & $\begin{array}{l}\infty \\
-1\end{array}$ & $\begin{array}{l}\vec{c} \\
-1\end{array}$ & \& & : & : & : \\
\hline & & & 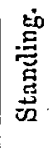 & 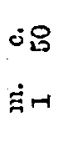 & - & ه & ब & 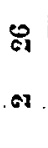 & $\begin{array}{l}8 \\
-1\end{array}$ & $\begin{array}{l}\mathscr{\Omega} \\
-1\end{array}$ & ?: & & $\because$ & : \\
\hline & \multirow{3}{*}{ 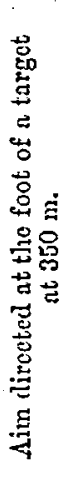 } & \multirow{3}{*}{ 宸 } & 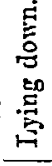 & $\begin{array}{l}\text { ¿ } \\
\dot{p} 0\end{array}$ & $\mathbb{\infty}$ & $\cong$ & $\begin{array}{l}8 \\
0 \\
-1\end{array}$ & $\overrightarrow{A i}$ & $\begin{array}{l}\infty \\
0\end{array}$ & $\begin{array}{l}\stackrel{12}{7} \\
0\end{array}$ & i & & : & : \\
\hline & & & 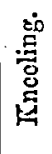 & $\begin{array}{l}\text { ن\& } \\
\text { jo }\end{array}$ & $\begin{array}{l}\text { हे } \\
\text {-1 }\end{array}$ & 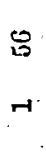 & $\begin{array}{l}\overrightarrow{20} \\
\vec{H}\end{array}$ & $\begin{array}{l}8 \\
\\
-1\end{array}$ & $\begin{array}{l}-19 \\
-1\end{array}$ & $\begin{array}{l}\text { 战 } \\
0\end{array}$ & i & : & : & : \\
\hline & & & 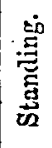 & 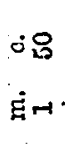 & $\vec{\infty}$ & 8 & $\begin{array}{l}\infty \\
\text { C }\end{array}$ & $\rightarrow$ & 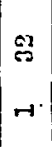 & $\begin{array}{l}010 \\
0\end{array}$ & i & : & : & $:$ \\
\hline & 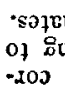 & & & 总 & 온 & 迆 & 20 & ه్ & 号 & 今. & 吕 & ఖ్లి & ஜ్లి & \& \\
\hline
\end{tabular}




\section{Table 8.}

Ordinates, at interrals of $50 \mathrm{~m}$. and abore a horizontal plane, of the $270 \mathrm{~m}$. line of sight, according as the firer is standing, knecling, or lying down, and aim taken at the foot or centre of the target.

\begin{tabular}{|c|c|c|c|c|c|c|}
\hline \multirow{3}{*}{$\begin{array}{l}\text { Distances } \\
\text { corresponding to } \\
\text { the ordinates. }\end{array}$} & \multicolumn{3}{|c|}{$\begin{array}{c}\text { Aim directed at the foot of a } \\
\text { target at } 270 \mathrm{~m} \text {. }\end{array}$} & \multicolumn{3}{|c|}{$\begin{array}{c}\text { Aim directed at the centre of a } \\
\text { target at } 270 \mathrm{~m} \text {. }\end{array}$} \\
\hline & \multicolumn{3}{|c|}{ Firing. } & \multicolumn{3}{|c|}{ Firing. } \\
\hline & Standing. & Fneeling. & $\begin{array}{l}\text { Lying } \\
\text { down. }\end{array}$ & Standing. & Ińnecling. & $\begin{array}{l}\text { Ising } \\
\text { down. }\end{array}$ \\
\hline $\begin{array}{c}\text { Mretres. } \\
\ldots\end{array}$ & $\begin{array}{l}\text { m. c. } \\
150\end{array}$ & $\begin{array}{ll}\text { m. } & \text { c. } \\
0 & 00\end{array}$ & 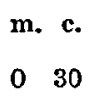 & $\begin{array}{l}\text { m. c. } \\
150\end{array}$ & $\begin{array}{l}\text { m. c. } \\
0 \quad 90\end{array}$ & $\begin{array}{l}\text { m. c. } \\
0 \quad 30\end{array}$ \\
\hline $.50 \ldots \ldots \ldots$ & 122 & 073 & 024 & 139 & 090 & o 4.2 \\
\hline $100 \ldots \ldots \ldots \ldots$ & $0 \quad 95$ & $0 \quad 57$ & $0 \quad 19$ & 128 & 090 & $0 \quad 53^{\prime}$ \\
\hline $150 \ldots \ldots \ldots \ldots$ & 067 & 040 & $0 \quad 13$ & 117 & 090 & 064 \\
\hline $200 \ldots \ldots \ldots \ldots$ & 0 39 & $0 \quad 23$ & $0 \quad 0 S$ & 106 & 090 & 075 \\
\hline $250 \ldots \ldots \ldots$ & $0 \quad 11$ & $\begin{array}{ll}0 & 07\end{array}$ & $\begin{array}{ll}0 & 02\end{array}$ & $0 \quad 94$ & 000 & $0 \quad 87$ \\
\hline $270 \ldots \ldots \ldots$ & $\bullet$ & *. & -. & 090 & 090 & 090 \\
\hline
\end{tabular}


THE UTILIZATION OF RIFLE FIRE IN THE FIELD. 831

\begin{tabular}{|c|c|c|c|c|c|c|c|c|c|c|c|c|}
\hline \multirow{3}{*}{ 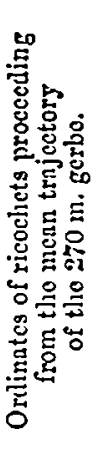 } & \multirow{3}{*}{ 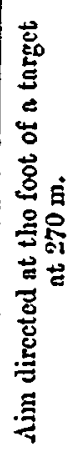 } & \multirow{3}{*}{ 害 } & 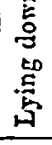 & \multicolumn{8}{|l|}{$\begin{array}{l}\dot{E} \\
\dot{E}\end{array}$} & r \\
\hline & & & 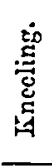 & \multicolumn{7}{|l|}{$\begin{array}{l}\dot{0} \\
\dot{a}\end{array}$} & $\begin{array}{l}\infty \\
0\end{array}$ & $\begin{array}{l}80 \\
21\end{array}$ \\
\hline & & & 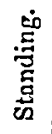 & \multicolumn{7}{|l|}{$\stackrel{\Xi}{ }$} & & -1 \\
\hline \multirow{7}{*}{ 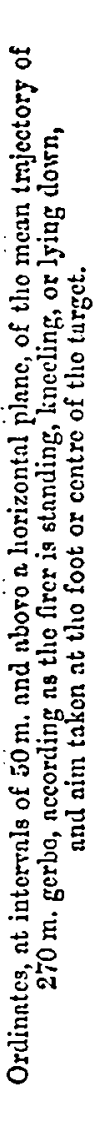 } & \multirow{3}{*}{ 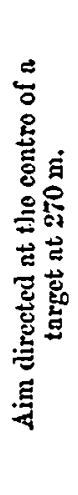 } & \multirow{3}{*}{ 总 } & 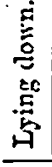 & $\begin{array}{l}\text { ¿० } \\
\text { घं० }\end{array}$ & $\begin{array}{l}\vec{\infty} \\
0\end{array}$ & $\begin{array}{l}\stackrel{29}{-1} \\
-1\end{array}$ & 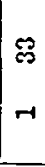 & $\rightarrow$ & \{ & 8 & : & : \\
\hline & & & 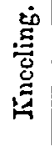 & $\begin{array}{l}\text { ن } \\
\text { घं }\end{array}$ & $\begin{array}{l}8 \\
-1\end{array}$ & r & $\leadsto$ & I2 & $\begin{array}{l}8 \\
-1\end{array}$ & 8 & : & : \\
\hline & & & 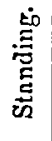 & $\begin{array}{l}\text { ن용 } \\
\dot{a}\end{array}$ & $\begin{array}{l}\infty \\
1 \\
-1\end{array}$ & $\begin{array}{l}8 \\
-1\end{array}$ & 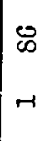 & $\overrightarrow{0}$ & $\begin{array}{l}\text { ને } \\
\text { r }\end{array}$ & $\begin{array}{l}8 \\
0\end{array}$ & : & : \\
\hline & \multirow{3}{*}{ 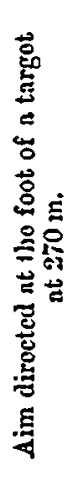 } & \multirow{3}{*}{ 害 } & 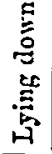 & $\begin{array}{l}\text { نू } \\
\text { घं० }\end{array}$ & 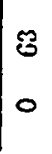 & 0 & 0 & 0 & $\begin{array}{l}a \\
0\end{array}$ & : & : & : \\
\hline & & & 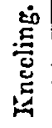 & $\begin{array}{l}\text { ن8 } \\
\text { ลं० }\end{array}$ & $\stackrel{\stackrel{9}{\sim}}{-1}$ & $\begin{array}{l}-1 \\
-1\end{array}$ & $\rightarrow$ & 足 & $\begin{array}{l}0 \\
0 \\
0\end{array}$ & : & : & : \\
\hline & & & 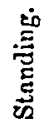 & 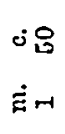 & 25 & 官 & 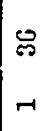 & $\overrightarrow{0}$ & 品 & : & : & : \\
\hline & \multicolumn{3}{|c|}{ 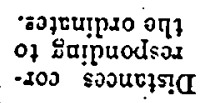 } & 触 & 8 & $\stackrel{9}{9}$ & 品 & 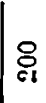 & 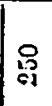 & 尽 & \&్లి & శ్లి \\
\hline
\end{tabular}


832 THE UTILIZATION OF RIFLE FIRE IN THE FIELD.

\begin{tabular}{|c|c|c|c|c|c|c|c|c|c|c|c|c|}
\hline \multirow{3}{*}{ 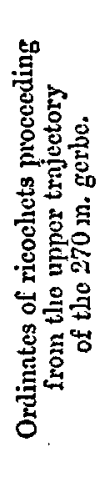 } & \multirow{3}{*}{ 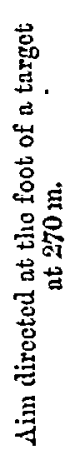 } & \multirow{3}{*}{ 它 } & 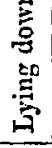 & \multicolumn{8}{|l|}{$\dot{0}$} & $\begin{array}{l}\text { s. } \\
\text { L } \\
0\end{array}$ \\
\hline & & & 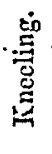 & & $\stackrel{\infty}{\infty}$ & $\begin{array}{l}5 \\
0 \\
0\end{array}$ \\
\hline & & & 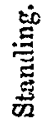 & & 읽 & $\begin{array}{l}23 \\
-1\end{array}$ \\
\hline \multirow{7}{*}{ 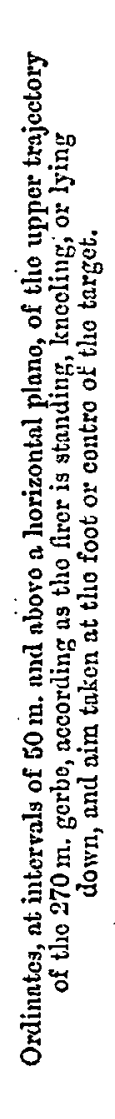 } & \multirow{3}{*}{ 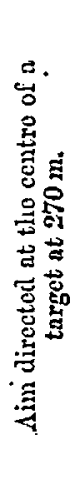 } & \multirow{3}{*}{ 苞 } & 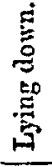 & $\begin{array}{l}\dot{8}: \\
\doteq 0\end{array}$ & $\begin{array}{l}20 \\
0 \\
0\end{array}$ & $\begin{array}{l}\mathscr{8} \\
-1\end{array}$ & $r$ & से & $\begin{array}{l}\mathscr{S} \\
-1 \\
-1\end{array}$ & $\begin{array}{l}\stackrel{10}{\rightarrow} \\
\rightarrow\end{array}$ & : & : \\
\hline & & & 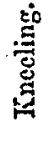 & $\begin{array}{l}\text { ن. } \\
\text { 三0. }\end{array}$ & $\begin{array}{l}\text { ๘ొ } \\
-\end{array}$ & $-r$ & $H$ & $\begin{array}{l}8 \\
0 \\
-1\end{array}$ & -1 & $\stackrel{49}{\rightarrow}$ & : & : \\
\hline & & & 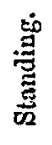 & $\begin{array}{l}ن .0 \\
\dot{\Xi}:-1\end{array}$ & $\begin{array}{l}\text { O) } \\
-1\end{array}$ & $\begin{array}{l}g \\
\square\end{array}$ & 足 & $\begin{array}{l}\mathscr{D} \\
-1 \\
-1\end{array}$ & 皇 & $\begin{array}{l}\stackrel{9}{H} \\
\rightarrow\end{array}$ & : & : \\
\hline & \multirow{3}{*}{ 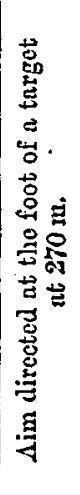 } & \multirow{3}{*}{ 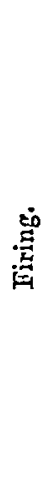 } & 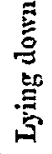 & $\begin{array}{l}\text { نO } \\
\text { 三0 }\end{array}$ & E & ? & 0 & $\begin{array}{l}8 \\
0\end{array}$ & $\begin{array}{l}2 \\
0\end{array}$ & $\begin{array}{l}2 \\
0\end{array}$ & : & : \\
\hline & & & 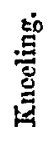 & $\begin{array}{l}\text { ن요 } \\
\text { ㅎㅇ }\end{array}$ & $\begin{array}{l}\stackrel{9}{r} \\
-1\end{array}$ & -1 & $\rightarrow$ & $\begin{array}{l}28 \\
0\end{array}$ & 9 & : & : & : \\
\hline & & & & $\begin{array}{l}58 \\
\dot{\Xi}-1\end{array}$ & 量 & $\begin{array}{l}8 \\
9\end{array}$ & $\neg$ & $\begin{array}{l}\Rightarrow \\
-1\end{array}$ & $\begin{array}{l}\text { 암 } \\
0\end{array}$ & $\begin{array}{l}98 \\
0 \\
0\end{array}$ & : & : \\
\hline & $\begin{array}{l}\text { Eoj } \\
\text { of } 8 \mathrm{su} \\
-.000\end{array}$ & $\begin{array}{l}\text { pro } \\
\text { prod }\end{array}$ & & : & 8 & § & $\stackrel{9}{9}$ & శ్ & 号 & 尽 & §్ & ⿸్ల్ల \\
\hline
\end{tabular}


THE UTILIZATION OF RIFLE FIRE IN THE FIELD. 833

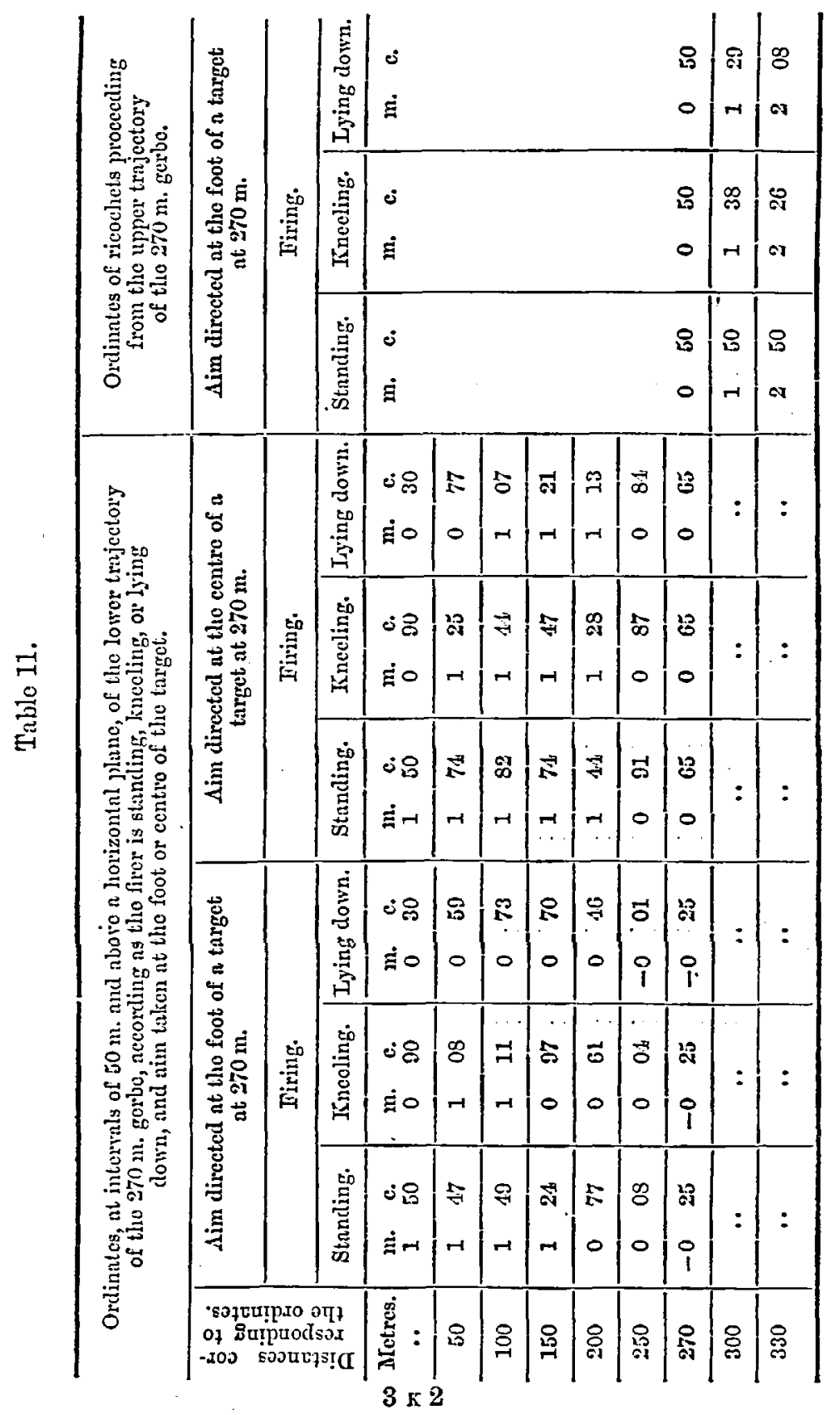


834 THE UTILIZATION OF RIFLE FIRE IN THE FIELD.

Table 12.

An approsimate comparison between the zone swept by the entire gerbe and the probable errors made in judging distance in the ficld.

\begin{tabular}{|c|c|c|}
\hline Distances. & $\begin{array}{l}\text { Zone swept by } \\
\text { entire gerbe. }\end{array}$ & $\begin{array}{l}\text { Probable error } \\
\text { in judging } \\
\text { distance. }\end{array}$ \\
\hline 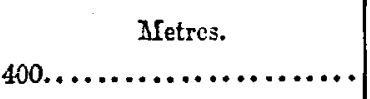 & $\begin{array}{l}\text { Metres. } \\
106\end{array}$ & $\begin{array}{c}\text { Metres. } \\
57\end{array}$ \\
\hline $450 \ldots \ldots \ldots \ldots \ldots \ldots \ldots$ & 62 & 61 \\
\hline $500 \ldots \ldots \ldots \ldots \ldots \ldots \ldots$ & $\underline{21}$ & 71 \\
\hline $600 \ldots \ldots \ldots \ldots \ldots \ldots \ldots$ & 5 & 85 \\
\hline
\end{tabular}


THE UTILIZATION OF RIFLE FIRE IN THE FIELD.

Table 13.

Interrals between the experimental targets deduced from the theoretical dangerous zones or "margins."

\begin{tabular}{|c|c|c|c|c|c|c|c|}
\hline 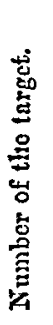 & 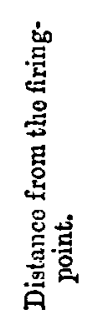 & 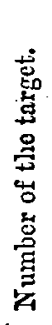 & 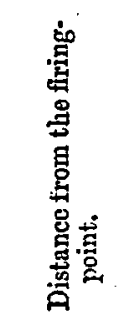 & 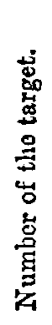 & 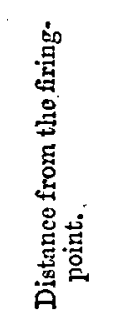 & 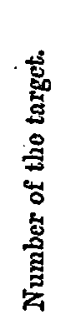 & 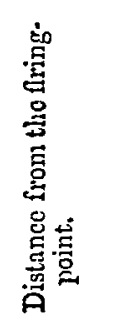 \\
\hline 1 & $\begin{array}{l}\text { MLetres. } \\
300\end{array}$ & 20 & $\begin{array}{c}\text { Metres. } \\
1015 \cdot 4\end{array}$ & 39 & $\begin{array}{c}\text { Metres. } \\
1313 \cdot 3\end{array}$ & 58 & $\begin{array}{l}\text { Metres. } \\
1526 \cdot 4\end{array}$ \\
\hline 2 & 400 & 21 & $103-4 \cdot 4$ & 40 & $1362 \cdot 2$ & 59 & $1536 \cdot 3$ \\
\hline $\mathbf{3}$ & 475 & 22 & $1052 \cdot 9$ & 41 & $1338 \cdot 0$ & 60 & $1516 \cdot 1$ \\
\hline 4 & 535 & 23 & $1070 \cdot 9$ & 42 & $135 \tilde{1} \cdot 4$ & 61 & $1555 \cdot 8$ \\
\hline 5 & $5 S 5 \cdot 8$ & 21 & $1083 \cdot 4$ & 43 & $1363 \cdot 7$ & 62 & $1565^{\circ} \cdot$ \\
\hline 6 & $629 \cdot 1$ & 25 & $1105 \cdot 9$ & 44 & $1375 \cdot 7$ & 63. & $1575 \cdot 2$ \\
\hline 7 & $669 \cdot 1$ & 26 & $1122 \cdot 9$ & 45 & $1387 \cdot 5$ & 64 & $1581 \cdot 8$ \\
\hline 8 & $706 \cdot 1$ & 27 & $1139 \cdot 5$ & 46 & $1399 \cdot 2$ & 65 & $1594 \cdot 3$ \\
\hline 9 & $742 \cdot 1$ & 28 & $1155^{\circ} 7$ & 47 & $1410 \cdot 7$ & 60 & $1603 \cdot 8$ \\
\hline 10 & $775 \cdot 6$ & 29 & $1171 \cdot 5$ & 48 & 1422 & 67 & $1613 \cdot 3$ \\
\hline 11 & $806 \cdot 1$ & 30 & $1186 \cdot 9$ & 49 & $1433 \cdot 1$ & 63 & $1622 \cdot 7$ \\
\hline 12 & $834 \cdot 5$ & 31 & $1201 \cdot 9$ & 50 & $1414 \cdot 2$ & 69 & 1632 \\
\hline 13 & $.860 \cdot 3$. & 32 & $1216 \cdot 7$ & 51 & 1455 & 70 & $16 \cdot 11 \cdot 3$ \\
\hline 14 & $88.1 \cdot 5$ & 33 & $1231 \cdot 2$ & 52 & $1465 \cdot 6$ & 71. & $1650 \cdot 6$ \\
\hline 15 & $908 \cdot 7$ & 31 & $1245 \cdot 5$ & 53 & $1476 \cdot 1$ & 72 & $1659 \cdot 8$ \\
\hline 16 & $931 \cdot 8$ & 35. & $1259 \cdot 5$ & 51 & $1486 \cdot 4$ & 73 & $1668 \cdot 9$ \\
\hline 17 & $953 \cdot 9$ & 36 & $1273 \cdot 3$ & 55 & $1496 \cdot 6$ & $\vdots 74 \cdot$ & $1677 \cdot 9$ \\
\hline 18 & 975 & 37 & $1286 \cdot 9$ & 56 & $1506 \cdot 6$ & 75 & $1686 \cdot 8$ \\
\hline 19 & 996 & 38 & $.1300: 2$. & 57 & $1516 \cdot 5$ & & \\
\hline
\end{tabular}


Table 17.

Serice with a combination of two sights.

\begin{tabular}{|c|c|c|c|c|c|c|c|}
\hline \multirow[b]{2}{*}{ 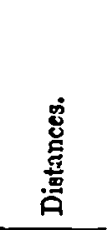 } & \multicolumn{3}{|c|}{$\begin{array}{l}\text { Series in tho Gemian } \\
\text { SIusketry Instructions. }\end{array}$} & \multicolumn{3}{|c|}{$\begin{array}{l}\text { Series carricd } 20 \mathrm{~m} \text {. } \\
\text { towards fring point.! }\end{array}$} & \multirow[b]{2}{*}{ Remarks. } \\
\hline & $\begin{array}{l}600 \mathrm{~m} . \\
\text { sight. }\end{array}$ & $\begin{array}{l}700 \mathrm{~m} . \\
\text { sight. }\end{array}$ & 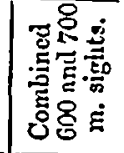 & $\begin{array}{l}600 \mathrm{~m} . \\
\text { sight. }\end{array}$ & $\begin{array}{l}700 \mathrm{~m} . \\
\text { Eight. }\end{array}$ & 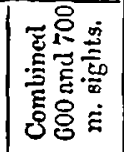 & \\
\hline $\begin{array}{c}\text { Arctrcs. } \\
410 \\
450 \\
460 \\
470 \\
430 \\
490 \\
500 \\
510 \\
520 \\
530 \\
540 \\
550 \\
560 \\
570 \\
580 \\
590 \\
600 \\
610 \\
620 \\
630 \\
640 \\
650 \\
660 \\
620 \\
650 \\
690 \\
700 \\
710 \\
720 \\
730 \\
740 \\
750 \\
760 \\
770 \\
780 \\
790 \\
800 \\
850 \\
820 \\
830 \\
810 \\
850 \\
860 \\
870 \\
\end{array}$ & 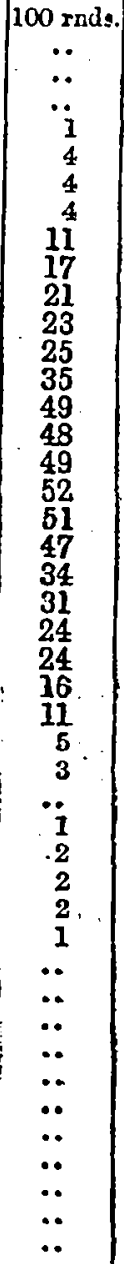 & 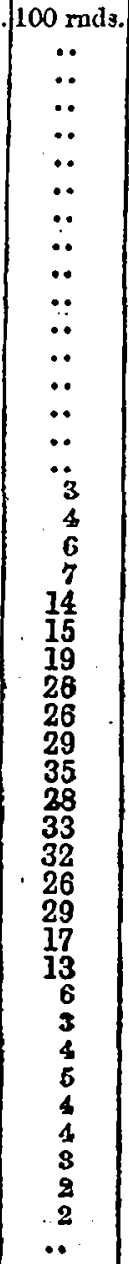 & \begin{tabular}{|c|c}
$00 \mathrm{rnd}$ \\
$\ldots$. \\
$\cdots$ \\
1. \\
1 \\
4 \\
4 \\
4 \\
11 \\
17 \\
21 \\
23 \\
25 \\
35 \\
49 \\
48 \\
49 \\
55 \\
55 \\
53 \\
41 \\
45 \\
39 \\
43 \\
42 \\
37 \\
34 \\
38 \\
28 \\
34 \\
34 \\
28 \\
31 \\
18 \\
13 \\
6 \\
3 \\
4 \\
5 \\
4 \\
4 \\
3 \\
2 \\
.2 \\
. \\
\end{tabular} & 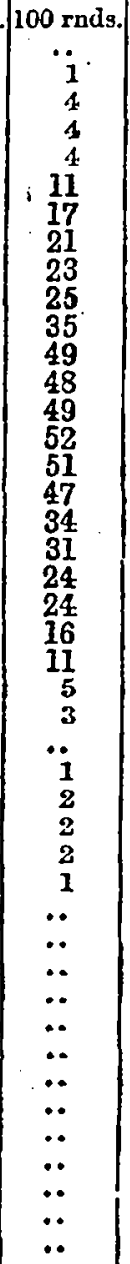 & 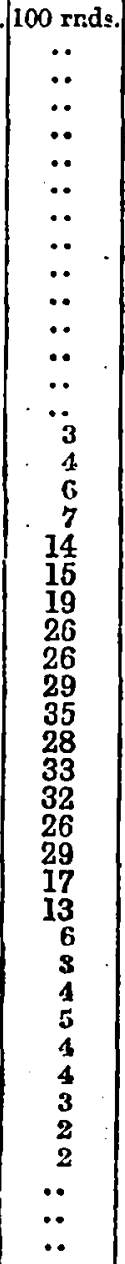 & \begin{tabular}{|c}
$200 \mathrm{rnds}$ \\
$\because$. \\
1 \\
4 \\
4 \\
4 \\
11 \\
17 \\
21 \\
23 \\
25 \\
35 \\
49 \\
48 \\
49 \\
55 \\
55 \\
53 \\
41 \\
45 \\
39 \\
43 \\
42 \\
37 \\
34 \\
38 \\
28 \\
34 \\
34 \\
28 \\
31 \\
18 \\
13 \\
6 \\
3 \\
4 \\
5 \\
4 \\
4 \\
3 \\
2 \\
2 \\
.. \\
.. \\
\end{tabular} & 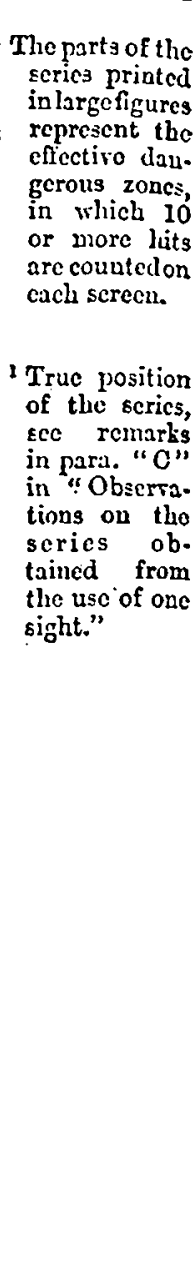 \\
\hline
\end{tabular}


Table 18.

Series with a combination of three sights.

\begin{tabular}{|c|c|c|c|c|c|c|}
\hline 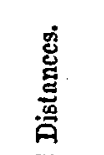 & $\begin{array}{l}1100 \mathrm{~m} . \\
\text { sight. }\end{array}$ & $\begin{array}{c}1200 \mathrm{~m} . \\
\text { sight. }\end{array}$ & $\begin{array}{c}1300 \mathrm{~m} . \\
\text { sight. }\end{array}$ & $\begin{array}{c}\text { Combined } \\
1100, \\
1200 \\
1300 \mathrm{~m} . \\
\text { sights. }\end{array}$ & $\begin{array}{c}\text { Combined } \\
1100, \\
1200, \\
1300 \mathrm{~m} . \\
\text { sights. }\end{array}$ & Remarks. \\
\hline $\begin{array}{c}11 \text { etres. } \\
990 \\
1000 \\
1010 \\
1020 \\
1030 \\
1010 \\
1050 \\
1060 \\
1070 \\
1080 \\
1090 \\
1100 \\
1110 \\
1120 \\
1130 \\
1140 \\
1150 \\
1160 \\
1170 \\
1180 \\
1190 \\
1200 \\
1210 \\
1220 \\
1230 \\
1210 \\
1250 \\
1260 \\
1270 \\
1280 \\
1290 \\
1300 \\
1310 \\
1320 \\
1330 \\
1340 \\
1350 \\
1360 \\
1370 \\
1380 \\
1390 \\
1400 \\
\end{array}$ & 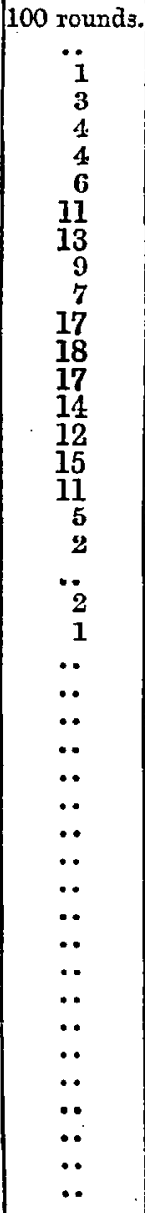 & 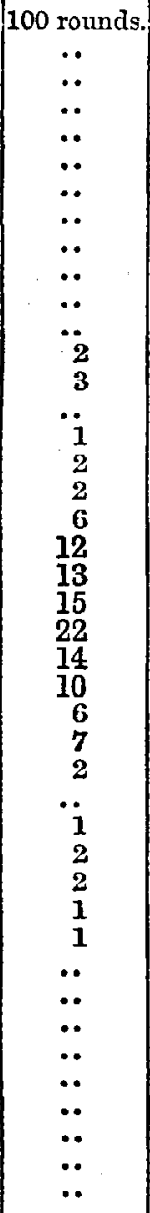 & 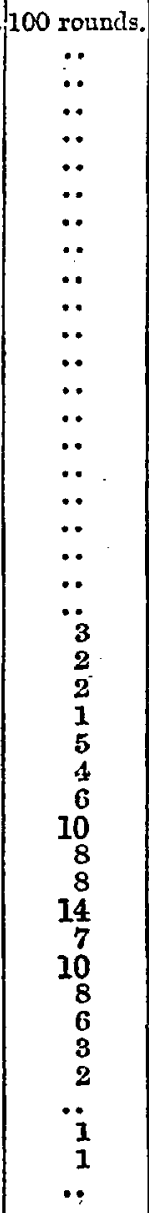 & \begin{tabular}{|c|c}
300 rounds. \\
7 \\
1 \\
3 \\
4 \\
4 \\
6 \\
11 \\
13 \\
9 \\
7 \\
17 \\
20 \\
20 \\
14 \\
13 \\
17 \\
13 \\
11 \\
14 \\
13 \\
17 \\
25 \\
16 \\
12 \\
7 \\
12 \\
6 \\
6 \\
11 \\
10 \\
10 \\
15 \\
8 \\
10 \\
8 \\
6 \\
3 \\
2 \\
$\cdots$. \\
1 \\
1
\end{tabular} & 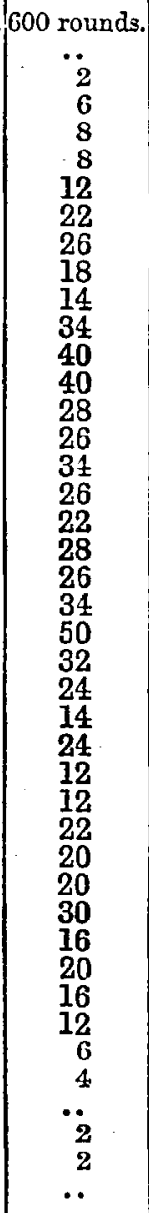 & $\begin{array}{l}\text { Each screen } \\
\text { recciring 10 } \\
\text { or more bits } \\
\text { has its re. } \\
\text { cord printed } \\
\text { in large fi- } \\
\text { gures. }\end{array}$ \\
\hline
\end{tabular}


Table 19.

Percentage of hits with one eight and with two; the distance unknown, and the series not displaced bs atmospleric inlluence.

\begin{tabular}{|c|c|c|c|}
\hline \multirow[b]{2}{*}{$\begin{array}{c}\text { Real distances. } \\
\text { Jletres. }\end{array}$} & \multicolumn{2}{|c|}{ Percentago with the-- } & \multirow[b]{2}{*}{ Remarks. } \\
\hline & $\begin{array}{l}600 \mathrm{~m} . \\
\text { sight. }\end{array}$ & $\begin{array}{c}\text { Combined } \\
600 \text { and } 700 \\
\text { m. sights. }\end{array}$ & \\
\hline $5 \% 0$ & 49 & $24 \cdot 5$ & \multirow{22}{*}{$\begin{array}{l}\text { It is assumed that the distance has } \\
\text { been judged to be } 650 \mathrm{~m} \text {.: the mean } \\
\text { error in judging being } \frac{1}{7} \text { of the real } \\
\text { distance, this may rary between } \\
\frac{650 \times 7}{6} \text { and } \frac{650 \times 7}{8} \text {, that is between } \\
760 \text { and } 570 \mathrm{~m} \text {. }\end{array}$} \\
\hline 580 & 52 & $27 \cdot 5$ & \\
\hline 590 & 51 & $27 \cdot 5$ & \\
\hline 600 & 47 & $26 \cdot 5$ & \\
\hline 610 & 34 & $20 \cdot 5=1$ & \\
\hline 620 & 31 & $22 \cdot 5$ & \\
\hline 630 & 24 & $19 \cdot 5$ & \\
\hline 610 & 24 & $21 \cdot 5$ & \\
\hline 650 & 16 & 21 & \\
\hline 660 & 11 & $18 \cdot 5$ & \\
\hline 670 & 5 & 17 & \\
\hline 680 & 3 & 19 & \\
\hline 690 & •. & 14 & \\
\hline 700 & 2 & 17 & \\
\hline 710 & 1 & 17 & \\
\hline 720 & 2 & 14 & \\
\hline 730 & 2 & $15 \cdot 5$ & \\
\hline 710 & 1 & 9 & \\
\hline 750 & •. & $6 \cdot 5$ & \\
\hline 760 & $\cdots$ & 3 & \\
\hline Total.... & 355 & $361 \cdot 5$ & \\
\hline Mean per cent. & $17 \cdot 75$ & $18 \cdot 07$ & \\
\hline
\end{tabular}

1 The terms of the series bare been taken from Table 17; the terms depending on the combination of two sights hare been dirided by two, to bring them into correspondence with an expenditure of 100 rounds with the single sight. 
THE UTILIZATION OF RIFLE FIRE IN THE FIELD.

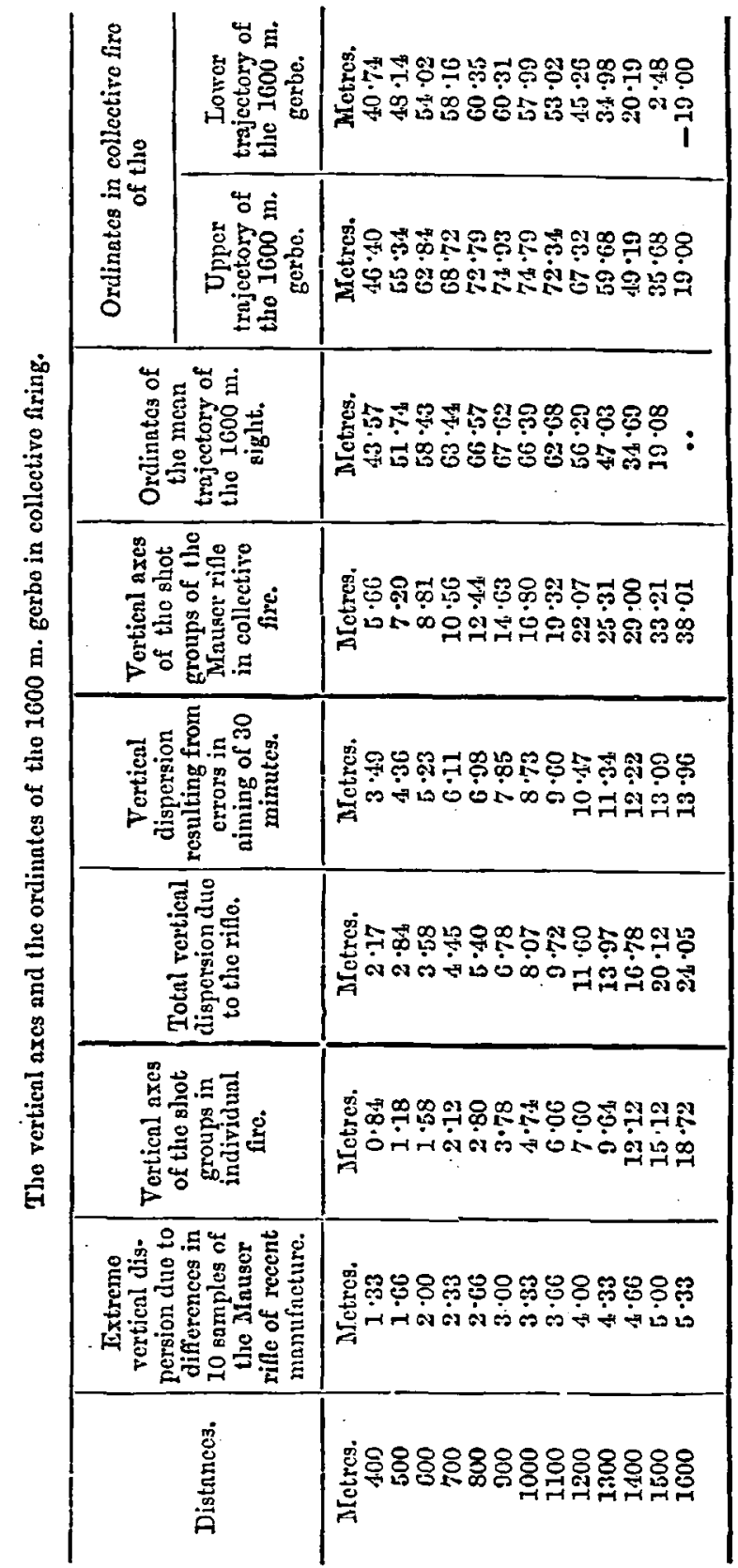


810 THE UTHIZATION OF RIFLE FIRE IN THE FIELD.

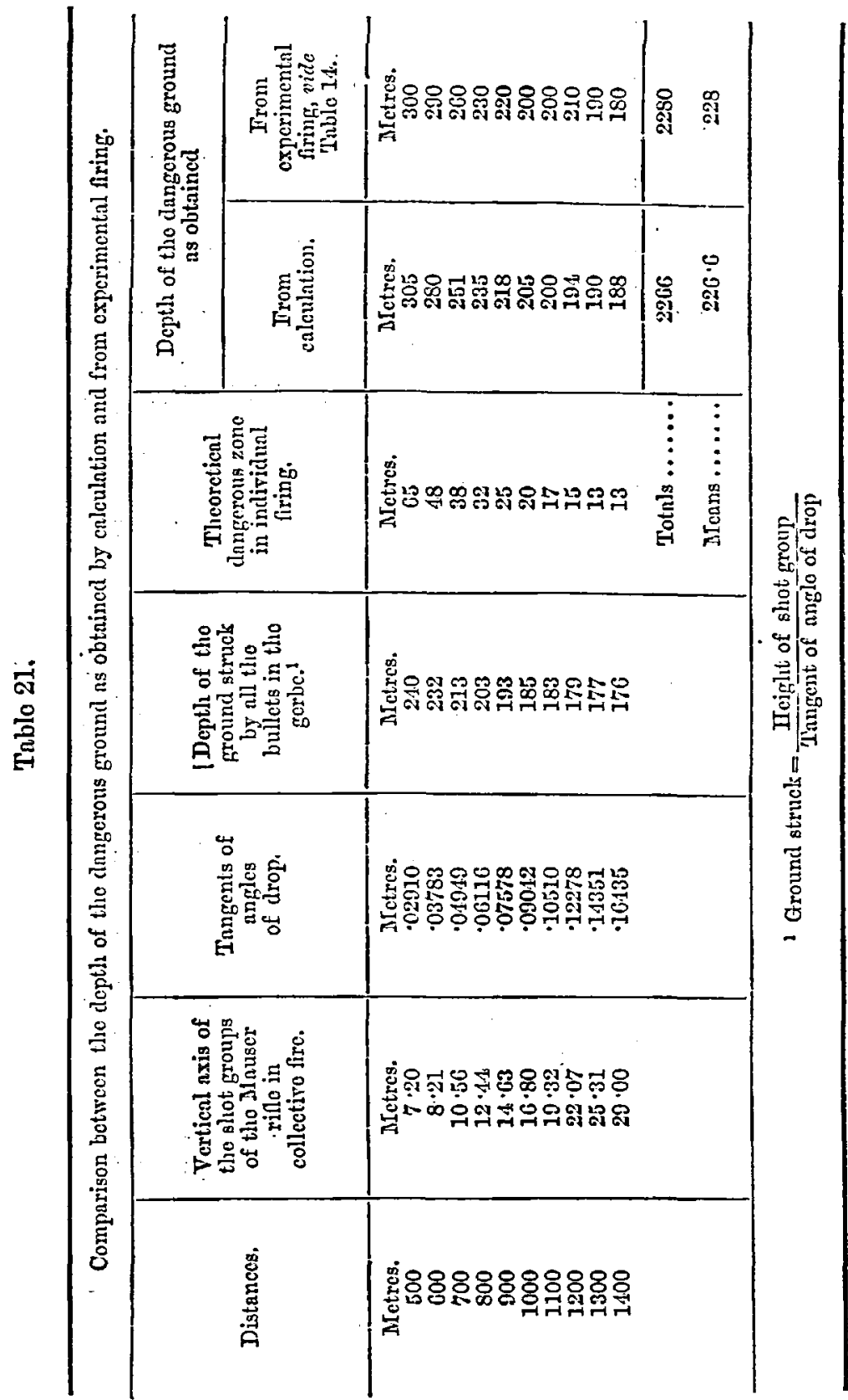


THE UTILIZATION OF RIFLE FIRE IN THE FIELD.

841

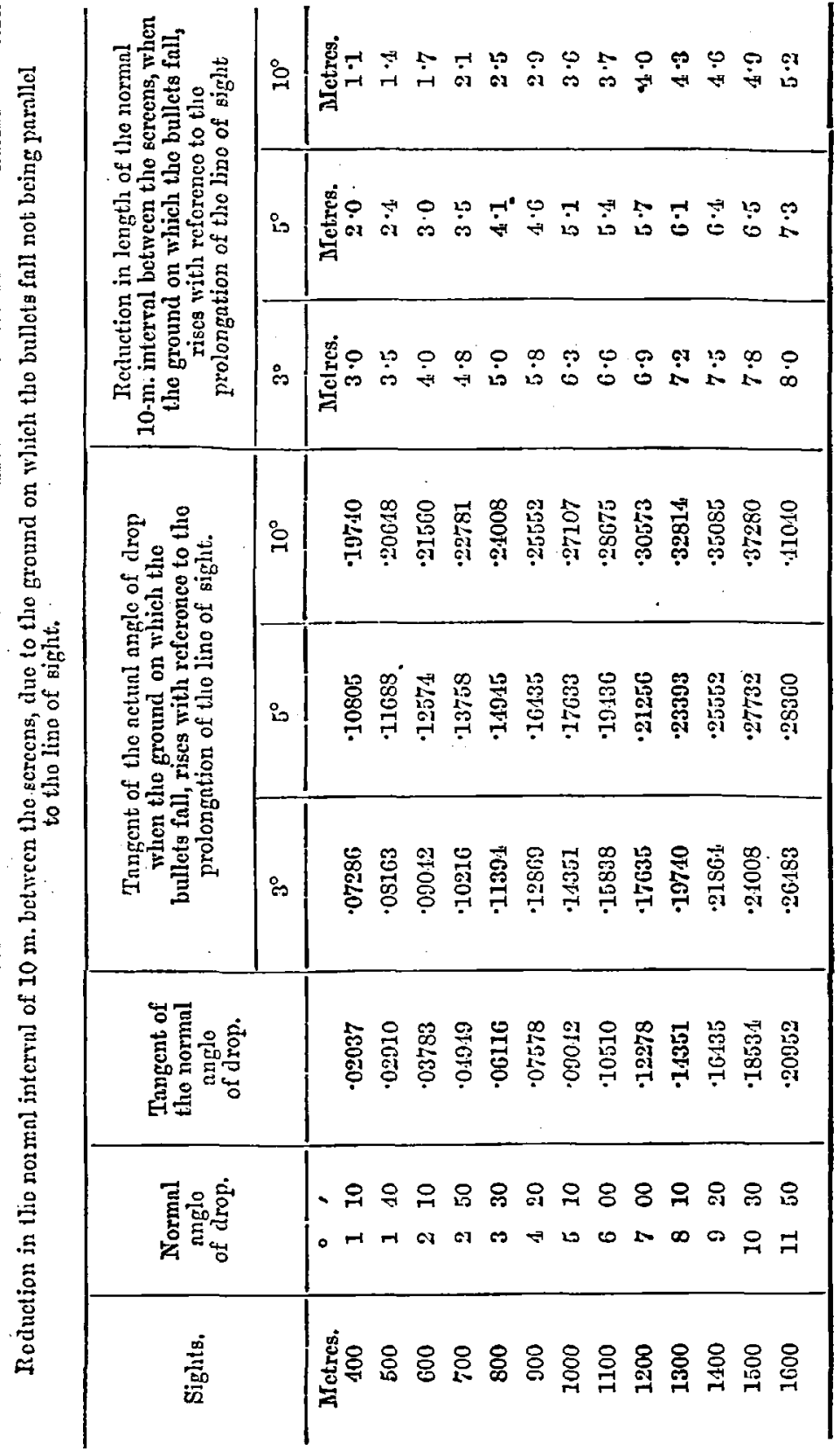


Comparison between the extent of the effective dangerous ground when the bullets fall on a surface parallel to the line of sight, or on one inclined to it.

\begin{tabular}{|c|c|c|c|c|c|}
\hline \multirow{3}{*}{ Sights. } & \multirow{3}{*}{$\begin{array}{l}\text { Number } \\
\text { of } \\
\text { rounds. }\end{array}$} & \multicolumn{4}{|c|}{ Depth of the effectire dangerous ground } \\
\hline & & \multirow{2}{*}{$\begin{array}{c}\text { When the } \\
\text { bullets fall } \\
\text { on a surface } \\
\text { parallel to } \\
\text { the line of } \\
\text { sight. }\end{array}$} & \multicolumn{3}{|c|}{$\begin{array}{l}\text { When the bullets fall on a surface } \\
\text { which makes with the line of sight } \\
\text { an angle of- }\end{array}$} \\
\hline & & & $+3^{\circ}$ & $+5^{\circ}$ & $+10^{\circ}$ \\
\hline \multirow[t]{2}{*}{$\begin{array}{c}\text { Metres. } \\
400 \\
500 \\
600 \\
700 \\
800 \\
100 \\
1000 \\
1100 \\
1200 \\
1300 \\
1400\end{array}$} & $\begin{array}{c}\text { Metres. } \\
100 \\
100 \\
100 \\
100 \\
100 \\
200 \\
200 \\
200 \\
200 \\
300 \\
300\end{array}$ & $\begin{array}{c}\text { Metres. } \\
210 \\
200 \\
170 \\
130 \\
110 \\
140 \\
110 \\
120 \\
80 \\
100 \\
110\end{array}$ & $\begin{array}{l}\text { Mictres. } \\
63 \\
75 \cdot 5 \\
68 \\
62 \cdot 4 \\
55 \\
81 \cdot 2 \\
69 \cdot 3 \\
79 \cdot 2 \\
55 \cdot 2 \\
72 \\
82 \cdot 5\end{array}$ & $\begin{array}{c}\text { Metres. } \\
42 \\
50 \cdot 4 \\
51 \\
43 \cdot 5 \\
45 \cdot 1 \\
61 \cdot 4 \\
56 \cdot 1 \\
64 \cdot 8 \\
45 \cdot 6 \\
61 \\
70 \cdot 4\end{array}$ & $\begin{array}{l}\text { Metres. } \\
23 \cdot 1 \\
29 \cdot 4 \\
28 \cdot 9 \\
27 \cdot 3 \\
27 \cdot 5 \\
40 \cdot 6 \\
39 \cdot 6 \\
44 \cdot 4 \\
32 \\
43 \\
50\end{array}$ \\
\hline & $\begin{array}{l}\text { Totals } \\
\text { Means }\end{array}$ & $\begin{array}{r}1450 \\
134\end{array}$ & $761 \cdot 3$ & $\begin{array}{c}594 \cdot 3 \\
54\end{array}$ & $\begin{array}{l}386 \cdot 4 \\
35\end{array}$ \\
\hline
\end{tabular}

